\title{
Ocean Dwelling Actinobacteria as Source of Antitumor Compounds
}

\author{
Ajitha Gomathi'; K M Gothandam ${ }^{1 *}$. \\ ${ }^{I}$ VIT University, School of Bio Sciences and Technology, India.
}

\begin{abstract}
Extending over decades, research has been of great focus and enormous progress on exploring the ocean for natural products from marine actinobacteria. Attraction towards alternative medicine has led to improvements in natural product discovery. With great potential to survive in extreme environments, marine actinobacteria, efficiently produce an array of metabolites with diverse bioactivity by evolving the secondary metabolic pathways. Exploiting the secondary metabolite producing potential of actinobacteria, many compounds with antitumor, antibacterial, antifungal, antimalarial, antiprotozoal, antiparasitic, antiviral, anti-parasitic, anti-inflammatory activities has been discovered. Efforts in bioprospecting alternative sources of natural products have thus led to several explorations and improvements in technologies which has decreased the bottle neck difficulties in the drug discovery process. Emphasizing on the recent advancements in bioactive compound production in actinobacteria, this paper comprises a review of the available literature, compiles the antitumor compounds from marine actinobacteria with brief discussions and the perspectives to develop better antitumor compounds which would stimulate further research.
\end{abstract}

Key words: Marine actinobacteria, bioactivity, antitumor compounds

*Authors for correspondence: gothandam@gmail.com 


\section{INTRODUCTION}

Outstanding biotechnological advances has improved our understanding and led to the achievement of great progress in developing drugs against cancer. Though present in the era of antibiotics, great challenges faced due to development of resistance in microbes and to anticancer drugs by malignant tumor cells has increased medical concern. These alarming needs prompt immediate action towards discovery and development of novel, potent and less toxic drugs. $60 \%$ of anticancer agents are derived from natural sources such as plants, marine organisms and micro-organisms. Bioactivities exhibited by the natural products have inspired the researchers to further probe the microbial sources for drug search. Microbes have a long history of use in the treatment of cancer. Microbial metabolites are among the most important of the cancer chemotherapeutic agents. From the 22,500 biologically active compounds that have been obtained so far from microbes, $45 \%$ are produced by actinomycetes, $38 \%$ by fungi and $17 \%$ by unicellular bacteria (Berdy 2005). Actinobacteria being prolific producers of secondary metabolites are novel candidates for synthesis of novel therapeutic drugs, efficient to combat a range of resistant microbes. Past history of extensive actinobacterial research, has proved limited realization of the actinomycete biosynthetic potential (Watve et al. 2001). Thus with considerable scope left over, potential efforts would efficiently increase the novel metabolite discovery.

Actinobacteria, a group of prokaryotic organisms are aerobic, nonmotile, filamentous, Gram-positive saprophytic bacteria with high guanosine-cytosine (GC) content in their DNA (70-80\%) (Goodfellow and Williams 1983). Actinobacteria belongs to the phyla actinobacteria which is one of the largest taxonomic unit and the order actinomycetales (Waksman 1959) which currently consists of 10 suborders, 49 families and over 160 genera. Widespread existence in natural ecosystems and greatest potential to produce bioactive compound has made actinobacteria to be greatly exploited for biotechnological applications. With overexploitation of terrestrial actinobacteria, the focus on marine sources for bioactive compounds gained significant momentum. Ocean, covering more than $70 \%$ of the Earth's surface is home to nearly one million multicellular (plants and animals) and one billion unicellular (distributed under 100 different phyla) organisms. (Burgess 2012). Actinobacteria exist with greatest biodiversity in oceans than in terrestrial ecosystems. Actinobacteria adapting to the extreme conditions of temperature, salinity and pressure, produce metabolites for their survival. The secondary metabolites produced by actinobacteria exhibit promising diverse biological activities and also possess varied chemical structures. Figure 1 represents the different biological activities exhibited by the secondary metabolites produced by marine actinobacteria with few listed examples. These metabolites are produced by biosynthetic gene clusters residing in the large genome of the actinobacteria. These clusters contain genes which are responsible for the production of different class of compounds with varied chemical structures. The different classes of compounds reported so far are polyketides, peptides, isoprenoids, indolocarbazoles, aminoglycosides, polyenes, macrolides and many more. These are synthesized by various genes encoding for enzymes such as polyketide synthases, non-ribosomal peptide synthase, dNDP-glucose 4,6 dehydratase, dTDPglucose 4,6 dehydratase, polyether epoxidase, OMethyl transferase, P450 Monoxygenase, AHBA synthase,

3-hydroxyl-3-methylglutaryl coenzymeA reductase, oxytryptophan dimertization enzyme, iadomycin cyclase etc. Figure 2 shows the schematic representation of some of the biosynthetic genes present in marine actinobacteria.

This review aims to compile the antitumor compounds from marine actinobacteria, mainly isolated from sea sediments. Table 1-6 comprises of the list of antitumor compounds from marine actinobacteria. The table also represents that a potential number of compounds has been obtained from actinobacteria belonging to Streptomyceteceae family. 
Biological activity of compounds produced by marine actinobacteria

\begin{tabular}{|c|l|}
\hline Antibacterial activity & $\begin{array}{l}\text { - Abyssomicins (Riedlinger et al. 2004) } \\
\text { - Tirandamycins (Carlson et al. 2009) }\end{array}$ \\
\hline - Chandrananimycin(Maskey et al. 2003) \\
\hline Antifungal activity & $\begin{array}{l}\text { N-(2-hydroxyphenyl)-2-phenazinamine (Gao et } \\
\text { al. 2012) }\end{array}$ \\
\hline Antitumor activity & $\begin{array}{l}\text { - Streptokordin (Jeong et al. 2006) } \\
\text { - Elaiomycins B and C (Helaly et al. 2011) }\end{array}$ \\
\hline Anti-inflammatory activity & $\begin{array}{l}\text { - Cyclomarins (Schultz et al. 2008) } \\
\text { - Salinamides A and B (Moore et al. 1999) }\end{array}$ \\
\hline Anti-malarial activity & \begin{tabular}{l} 
- Trioxacarcin (Maskey et al. 2004) \\
\hline Anti-viral activity
\end{tabular} \\
\hline Anti-parasitic activity & - Benzastatin C (Lee et al. 2007) \\
\hline
\end{tabular}

Figure 1-- Different biological activity of secondary metabolites produced by marine actinobacteria.

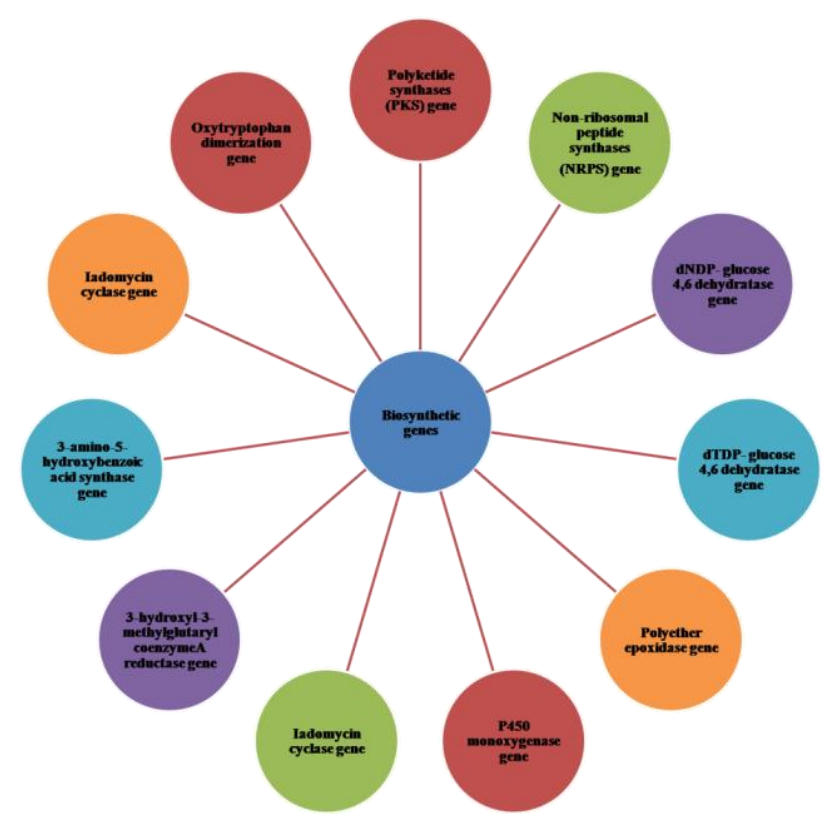

Figure 2 -- Secondary metabolite biosynthetic genes present in marine actinobacteria.

\section{ANTITUMOR COMPOUNDS FROM MARINE ACTINOBACTERIA}

\section{Polyketides}

Table 1 represents the list of compounds from marine actinobacteria with polyketides as chemical structure.
Polyketides are a significant class of compounds exhibiting wide range of pharmacological activities. Three types of polyketide synthases namely type I, II, III, catalyse the condensation reactions of acyl-CoA precursors to produce different polyketides. 
Table 1- Compounds with polyketide as chemical structure

\begin{tabular}{|c|c|c|c|c|c|}
\hline Compound & Source & Organism & Family & Cancer & Reference \\
\hline SS-228 Y & Sagami Bay & Streptomyces sp. & Streptomyceteceae & $\begin{array}{l}\text { Ehrlich breast } \\
\text { adenocarcinoma }\end{array}$ & $\begin{array}{l}\text { Okazaki et } \\
\text { al. } 1975\end{array}$ \\
\hline $\begin{array}{l}\text { Fridamycins (A,B,D) } \\
\text { Himalomycin A, B } \\
\text { Rabelomycin }\end{array}$ & $\begin{array}{l}\text { Mauritius } \\
\text { (Indian ocean) }\end{array}$ & $\begin{array}{l}\text { Streptomyces sp } \\
\text { isolate B6921 }\end{array}$ & Streptomyceteceae & & $\begin{array}{l}\text { Maskey et } \\
\text { al. } 2003\end{array}$ \\
\hline Aureoverticillactam & $\begin{array}{l}\text { Marine } \\
\text { sediment }\end{array}$ & $\begin{array}{l}\text { Streptomyces } \\
\text { Aureoverticillatus } \\
\text { (NPS001583) }\end{array}$ & Streptomyceteceae & $\begin{array}{l}\text { Colorectal } \\
\text { adenocarcinoma, } \\
\text { Melanoma, } \\
\text { Leukemia }\end{array}$ & $\begin{array}{l}\text { Mitchell } \\
\text { et al. } 2004\end{array}$ \\
\hline $\begin{array}{l}\text { (R)-10-methyl-6- } \\
\text { undecanolide } \\
\text { (6R, 10S)-10- } \\
\text { methyl-6- } \\
\text { dodecanolide) }\end{array}$ & $\begin{array}{l}\text { Papua New } \\
\text { Guinea }\end{array}$ & $\begin{array}{l}\text { Streptomyces sp. } \\
\text { B6007 }\end{array}$ & Streptomyceteceae & $\begin{array}{l}\text { Gastric } \\
\text { adenocarcinoma, } \\
\text { Hepatocarcinoma, } \\
\text { Breast cancer }\end{array}$ & $\begin{array}{l}\text { Stritzke et } \\
\text { al. } 2004\end{array}$ \\
\hline Chartreusin & $\begin{array}{l}\text { Jiaozhou Bay, } \\
\text { China }\end{array}$ & $\begin{array}{l}\text { Streptomyces sp. } \\
\text { Strain M518 }\end{array}$ & Streptomyceteceae & $\begin{array}{l}\text { Melanoma } \\
\text { Leukemia }\end{array}$ & $\begin{array}{l}\text { Wu et al. } \\
2006 \text {; } \\
\text { McGovren } \\
\text { et al. } 1977\end{array}$ \\
\hline $\begin{array}{l}\text { Actinofuranones A, } \\
\text { B }\end{array}$ & $\begin{array}{l}\text { Sediment } \\
\text { sample from } \\
\text { Guam }\end{array}$ & $\begin{array}{l}\text { Streptomyces } \\
\text { Strain CNQ766 }\end{array}$ & Streptomyceteceae & & $\begin{array}{l}\text { Cho et al. } \\
2006\end{array}$ \\
\hline Nonactin & $\begin{array}{l}\text { Sediment } \\
\text { sample Ayu } \\
\text { Trough }\end{array}$ & $\begin{array}{l}\text { Streptomyces sp. } \\
\text { KORDI-3238 }\end{array}$ & Streptomyceteceae & $\begin{array}{l}\text { Human } \\
\text { erythroleukemia }\end{array}$ & $\begin{array}{l}\text { Jeong et } \\
\text { al. } 2006 ; \\
\text { Borrel et } \\
\text { al. } 2005\end{array}$ \\
\hline $\begin{array}{l}\text { Manumycin } \\
\text { Chinikomycin A,B }\end{array}$ & $\begin{array}{l}\text { Jiaozhou Bay, } \\
\text { China }\end{array}$ & $\begin{array}{l}\text { Streptomyces sp. } \\
\text { isolate M045 }\end{array}$ & Streptomyceteceae & $\begin{array}{l}\text { Renal cancer } \\
\text { Mammary cancer } \\
\text { Melanoma }\end{array}$ & $\begin{array}{l}\text { Li et al. } \\
2005\end{array}$ \\
\hline Daryamides A,B & $\begin{array}{l}\text { San Diego, } \\
\text { California }\end{array}$ & $\begin{array}{l}\text { Streptomyces } \\
\text { strain } \\
\text { CNQ-085 }\end{array}$ & Streptomyceteceae & $\begin{array}{l}\text { Human colon } \\
\text { carcinoma }\end{array}$ & $\begin{array}{l}\text { Asolkar et } \\
\text { al. } 2006\end{array}$ \\
\hline $\begin{array}{l}\text { Marinomycins } \\
\text { A,B,C,D }\end{array}$ & $\begin{array}{l}\text { La Jolla, } \\
\text { California }\end{array}$ & $\begin{array}{l}\text { Marinispora sp. } \\
\text { strain CNQ-140 }\end{array}$ & Streptomyceteceae & $\begin{array}{l}\text { Human } \\
\text { melanoma }\end{array}$ & $\begin{array}{l}\text { Kwon et } \\
\text { al. } 2006\end{array}$ \\
\hline Saliniketals A and B & $\begin{array}{l}\text { Sediment } \\
\text { sample from } \\
\text { Guam }\end{array}$ & $\begin{array}{l}\text { Salinispora } \\
\text { arenicola } \\
\text { strain CNR-005 }\end{array}$ & Micromonosporaceae & & $\begin{array}{l}\text { Williams } \\
\text { et al. } \\
2007 \mathrm{a} \text {; } \\
\text { Jensen et } \\
\text { al. } 2007\end{array}$ \\
\hline Arenicolides A & $\begin{array}{l}\text { Sediment } \\
\text { sample from } \\
\text { Guam }\end{array}$ & $\begin{array}{l}\text { Salinispora } \\
\text { arenicola } \\
\text { strain CNR-005 }\end{array}$ & Micromonosporaceae & $\begin{array}{l}\text { Human colon } \\
\text { adenocarcinoma }\end{array}$ & $\begin{array}{l}\text { Williams } \\
\text { et al. } \\
2007 b\end{array}$ \\
\hline Chalcomycin A & $\begin{array}{l}\text { Jiaozhou Bay, } \\
\text { China; } \\
\text { Pohoiki, } \\
\text { Hawaii, } \\
\quad \text { Pacific } \\
\text { ocean }\end{array}$ & $\begin{array}{l}\text { Streptomyces sp. } \\
\text { strain M491; } \\
\text { Streptomycete } \\
\text { isolate B7064 }\end{array}$ & Streptomyceteceae & $\begin{array}{l}\text { Human cervix } \\
\text { carcinoma }\end{array}$ & $\begin{array}{l}\text { Wu et al. } \\
2007 ; \\
\text { Asolkar et } \\
\text { al. } 2002\end{array}$ \\
\hline Piericidins C7, C8 & $\begin{array}{l}\text { Iwayama Bay, } \\
\text { Palau }\end{array}$ & $\begin{array}{l}\text { Streptomyces sp. } \\
\text { YM14-060 }\end{array}$ & Streptomyceteceae & & $\begin{array}{l}\text { Hayakawa } \\
\text { et al. } \\
2007 a \text {; } \\
\text { Hayakawa } \\
\text { et al. } \\
2007 b\end{array}$ \\
\hline
\end{tabular}




\begin{tabular}{|c|c|c|c|c|c|}
\hline $\begin{array}{l}\text { Resistoflavine, } \\
\text { 1-hydroxy-1- } \\
\text { norresistomycin }\end{array}$ & $\begin{array}{l}\text { Machilipatnam } \\
\text { coast, } \\
\text { Bay of Bengal, } \\
\text { India }\end{array}$ & $\begin{array}{l}\text { Streptomyces } \\
\text { chibaensis } \\
\text { (strain } \\
\text { AUBN1/7) }\end{array}$ & Streptomyceteceae & $\begin{array}{l}\text { Gastric } \\
\text { adenocarcinoma, } \\
\text { Hepatic } \\
\text { carcinoma }\end{array}$ & $\begin{array}{l}\text { Gorajana } \\
\text { et al. } \\
\text { 2005; } \\
\text { Gorajana } \\
\text { et al. } 2007\end{array}$ \\
\hline Marmycins A,B & $\begin{array}{l}\text { Sea of Cortez, } \\
\text { Baja } \\
\text { California Sur, } \\
\text { México }\end{array}$ & $\begin{array}{l}\text { Streptomyces } \\
\text { strain CNH990 }\end{array}$ & Streptomyceteceae & $\begin{array}{l}\text { Colon } \\
\text { adenocarcinoma, } \\
\text { Breast cancer, } \\
\text { Prostate cancer, } \\
\text { Lung cancer , } \\
\text { Leukemia }\end{array}$ & $\begin{array}{l}\text { Martin et } \\
\text { al. } 2007\end{array}$ \\
\hline $\begin{array}{l}\text { Mansouramycin } \\
\text { A,B,C,D }\end{array}$ & $\begin{array}{l}\text { North Sea } \\
\text { coast, } \\
\text { Germany }\end{array}$ & $\begin{array}{l}\text { Streptomyces } \\
\text { strain Mei37 }\end{array}$ & Streptomyceteceae & $\begin{array}{l}\text { Non-small cell } \\
\text { lung cancer, } \\
\text { Breast cancer, } \\
\text { Melanoma, } \\
\text { Prostate cancer }\end{array}$ & $\begin{array}{l}\text { Hawas et } \\
\text { al. } 2009\end{array}$ \\
\hline Albidopyrone & Atlantic ocean & $\begin{array}{l}\text { Streptomyces sp. } \\
\text { NTK } 227\end{array}$ & Streptomyceteceae & & $\begin{array}{l}\text { Hohmann } \\
\text { et al. } \\
\text { 2009a }\end{array}$ \\
\hline Tartrolon D & $\begin{array}{l}\text { East coast of } \\
\text { Madagaskar }\end{array}$ & $\begin{array}{l}\text { Streptomyces sp. } \\
\text { MDG-04-17-069 }\end{array}$ & Streptomyceteceae & $\begin{array}{l}\text { Lung carcinoma, } \\
\text { Colorectal } \\
\text { carcinoma, } \\
\text { Breast } \\
\text { adenocarcinoma }\end{array}$ & $\begin{array}{l}\text { Perez et } \\
\text { al. } 2009\end{array}$ \\
\hline $\begin{array}{l}\text { Caerulomycin } \\
(\mathrm{F}, \mathrm{G}, \mathrm{H}, \mathrm{I}, \mathrm{J}, \mathrm{K})\end{array}$ & Weihai, China & $\begin{array}{l}\text { Actinoalloteichus } \\
\text { cyanogriseus } \\
\text { WH1-2216-6 }\end{array}$ & Actinomycetaceae & $\begin{array}{l}\text { Human } \\
\text { promyelocytic } \\
\text { leukemia, } \\
\text { Human alveolar } \\
\text { adenocarcinoma, } \\
\text { Human chronic } \\
\text { myelogenous } \\
\text { leukemia, } \\
\text { Human } \\
\text { epidermoid } \\
\text { carcinoma. }\end{array}$ & $\begin{array}{l}\text { Fu et al. } \\
2011 \mathrm{a}\end{array}$ \\
\hline $\begin{array}{l}\text { Cyanogrisides } \\
\text { A,B,C,D }\end{array}$ & Weihai, China & $\begin{array}{l}\text { Actinoalloteichus } \\
\text { cyanogriseus } \\
\text { WH1-2216-6 }\end{array}$ & Actinomycetaceae & $\begin{array}{l}\text { Breast cancer, } \\
\text { Human } \\
\text { epidermoid } \\
\text { carcinoma, } \\
\text { Human chronic } \\
\text { myelogenous } \\
\text { leukemia }\end{array}$ & $\begin{array}{l}\text { Fu et al. } \\
2011 b\end{array}$ \\
\hline
\end{tabular}

A species of Chainia (now Streptomyces) isolated from shallow sea mud in Sagami Bay, produced a compound SS-228 Y which inhibited the growth of Ehrlich carcinoma in mice. SS-228 Y inhibits growth of Ehrlich breast adenocarcinoma in mice. Administering SS-228 Y in mice inoculated with Ehrlich ascites tumor, for 10 days at doses of more than $1.56 \mu \mathrm{g}$ per day, prolonged the survival period of the mice (Okazaki et al. 1975). Fridamycins $(\mathrm{A}, \mathrm{B}, \mathrm{D})$, himalomycin $\mathrm{A}$ and $\mathrm{B}$, and rabelomycin were reported to be produced by Streptomyces sp. isolate B6921 isolated from sandy sediment of a coastal site of Mauritius (Indian Ocean). These antibiotics possess antibacterial and antitumor activities (Maskey et al. 2003). Aureoverticillactam, a macrocyclic lactam was found to be produced by Streptomyces aureoverticillatus (NPS001583) isolated from a marine sediment. The 22 atom macrocylic lactam has exhibited moderate cytotoxic activity against colorectal adenocarcnioma, melanoma, and leukemia cell lines (Mitchell et al. 2004). A new class of compounds (R)-10-methyl-6-undecanolide and (6R, 10S)-10-methyl-6-dodecanolide belonging to caprolactones are extracted by ethyl acetate from the marine actinomycete Streptomyces 
sp. B6007. This species was isolated from the mangrove sediment, Papua New Guinea. The compounds (6R, 10S)-10-methyl-6-dodecanolide have shown action against gastric adenocarcinoma (HM02), hepatocarcinoma cell lines (HepG2), and breast cancer cell lines (MCF-7) (Stritzke et al. 2004).

$\mathrm{Wu}$ et al. (2006) reported the production of chartreusin from Streptomyces sp. M518, derived from a sediment of Jiaozhou Bay in China. Chartreusin causes DNA damage by binding to the DNA and inhibiting RNA and DNA synthesis. Chartreusin was found to be potent inhibitors of the catalytic activity of topoisomerase II (Lorico and Long 1993). Chartreusin exhibited vital chemotherapeutic activity against tumor cell lines such as murine (P388), leukemia (L1210) and melanoma (B16) (McGovren et al. 1977). Cho et al. (2006) reported two new secondary metabolites, namely, actinofuranones A and B produced by marine-derived Streptomyces strain designated as CNQ766, which was isolated from sediment sample collected from Guam. In vitro cytotoxicity tests revealed weak activity of the polyketides against mouse splenocyte T-cells and macrophages with $\mathrm{IC}_{50}$ values of $20 \mu \mathrm{g} / \mathrm{mL}$.

Streptomyces sp. KORDI-3238 isolated from deepsea sediment sample collected at Ayu Trough, in the western Pacific ocean, produced an ionophore antibiotic macrolide, nonactin (Jeong et al. 2006). Borrel et al. (2005) reported nonactin to possess antitumor activity and to be an effective inhibitor against multidrug-resistant human erythroleukemia cell line K562. Manumycins belong to a class of cytotoxic compounds with side chains consisting of polyketide-derived moieties. The compounds exhibited various other biological activities also. Manumycin A and two novel antitumor antibiotics, chinikomycins A and B were isolated from a marine Streptomyces sp. M045, derived from sediment of Jiaozhou Bay in China. These chlorine-containing manumycin derivatives exhibited antitumor activity against different human cancer cell lines namely renal cancer, mammary cancer, melanoma cell line, among which chinikomycin A was potent than chinikomycin B. Chinicomycin A selectively inhibited proliferation in cell lines of mammary cancer MAXF 401NL ( $\mathrm{IC}_{50}$ value of $2.41 \mu \mathrm{g} / \mathrm{mL}$ ), melanoma MEXF $462 \mathrm{NL}$ ( $\mathrm{IC}_{50}$ value of 4.15 $\mu \mathrm{g} / \mathrm{mL}$ ), and renal cancer RXF 944L ( $\mathrm{IC}_{50}$ value of $4.02 \mu \mathrm{g} / \mathrm{mL}$ ). Chinikomycin B showed selective antitumor activity against MAXF 401NL ( IC $_{50}$ value of $3.04 \mu \mathrm{g} / \mathrm{mL}$ ) (Li et al. 2005). Streptomyces strain CNQ-085 was isolated from marine sediment collected at a depth of $50 \mathrm{~m}$ off San Diego, California. The culture extracts of strain CNQ-085 yielded four new moderately cytotoxic compounds, designated as daryamides A, B, C and (2E,4E)-7methylocta-2,4-dienoic acid amide. The side chains in the compounds appear to be typical polyketide-derived moieties. Daryamide A exhibited potent cancer cell cytotoxicity $\left(\mathrm{IC}_{50}\right.$ value of $3.15 \mu \mathrm{g} / \mathrm{mL}$ ) in the evaluation of cytotoxicity against human colon carcinoma cell line, HCT-116 (Asolkar et al. 2006). Marinispora sp. CNQ-140 was isolated from a sediment sample collected at a depth of $56 \mathrm{~m}$ offshore of La Jolla, California. The culture extract of the strain led to the isolation of marinomycins A-D which are macrodiolides composed of dimeric 2-hydroxy-6-alkenyl-benzoic acid lactones with conjugated tetraenepentahydroxy polyketide chains. The compounds inhibited cancer cell proliferation when tested against the NCI's 60 cancer cell line panel with average $\mathrm{LC}_{50}$ values of $0.2-2.7 \mu \mathrm{M}$. Significant tissue type selectivity was exhibited by marinomycin A against human melonama cell lines LOX IMVI, M14, SK-MEL-2, SK-MEL-5, UACC257, and UACC-62, while SK-MEL-5 was the most sensitive strain was with an LC50 of $5.0 \mathrm{nM}$. Marinomycins $\mathrm{B}$ and $\mathrm{C}$ also showed potent activities with average LC50 values of 0.9 and 0.2 $\mu \mathrm{M}$, respectively (Kwon et al. 2006).

Marine actinomycete Salinispora arenicola strain CNR-005, was isolated from a sediment sample collected in Guam at a depth of approximately 30 $\mathrm{m}$. The strain has led to the isolation of two unusual bicyclic polyketides, saliniketals $\mathrm{A}$ and $\mathrm{B}$ containing a new 1,4-dimethyl-2,8dioxabicyclo[3.2.1]octan-3-yl ring. Saliniketals A and $\mathrm{B}$ were found to inhibit ornithine decarboxylase induction, an important target for the chemoprevention of cancer, with $\mathrm{IC}_{50}$ values of 1.95 and $7.83 \mu \mathrm{g} / \mathrm{mL}$, respectively (Williams et al. 2007a; Jensen et al. 2007). Salinispora arenicola CNR-005 also produced three new macrolide polyketides designated arenicolides A-C which are 26-membered polyunsaturated macrolactones containing repeating vicinal hydroxyl methoxyl moieties. Arenicolide A exhibited moderate cytotoxicity toward the HCT-116 cell lines with $\mathrm{IC}_{50}$ value of $30 \mu \mathrm{g} / \mathrm{mL}$ (Williams et al. 2007b). Streptomyces sp. M491, derived from sediment of Jiaozhou Bay in China, produced macrolide antibiotic chalcomycin A, along with many other compounds (Wu et al. 2007). Another 
Streptomycete isolate B7064 derived from mangrove sediment near Pohoiki, Hawaii (Pacific ocean), also produced chalcomycin B. Chalcomycin has been found to inhibit protein synthesis in HeLa human cervix carcinoma cell line (Asolkar et al. 2002; Wu et al. 2007). Streptomyces sp. YM14-060 was isolated from unidentified greenish ascidians collected at Iwayama Bay, Palau. The isolate produced piericidins $\mathrm{C} 7$ and $\mathrm{C} 8$, two new members of the piericidin family (Hayakawa et al. 2007a). Rat glial cells transformed with the adenovirus E1A gene (RGE1A-7), neuro-2a mouse neuroblastoma cells, C6 rat glioma cells and $3 \mathrm{Y} 1$ rat normal fibroblasts were used for examining the biological activities of piercidins. Piericidins $\mathrm{C} 7$ and $\mathrm{C} 8$ exhibited selective cytotoxicity against RG-E1A-7 cells (IC50 of $1.5 \mathrm{nM}$ and $0.45 \mathrm{nM}$, respectively), and inhibited the growth of Neuro-2a cells $\left(\mathrm{IC}_{50}\right.$ of 0.83 $\mathrm{nM}$ and $0.21 \mathrm{nM}$, respectively) without cytotoxic cell death, while piericidins were not cytotoxic nor cytostatic on C6 rat glioma cells and 3Y1 rat normal fibroblast (Hayakawa et al. 2007b).

Streptomyces chibaensis (strain AUBN1/7) was isolated from a marine sediment sample collected at a depth of $30 \mathrm{~m}$ at a distance of $8 \mathrm{~km}$ off Machilipatnam coast of Bay of Bengal, India. The culture extract of the strain yielded 1-hydroxy-1norresistomycin and resistoflavine. Both the metabolites showed a potent in vitro cytotoxic activity against cell lines namely, HMO2 and HePG2 (Gorajana et al. 2005; Gorajana et al. 2007). Streptomyces-related strain CNH990 was obtained from sediment samples collected at the entrance of Sea of Cortez, Baja California Sur, México. The strain yielded two new cytotoxic quinones of the angucycline class, marmycins A and B. Initially the cytotoxic behavior of the compounds were evaluated against the HCT-116 cell lines, in which marmycin $\mathrm{A}$ and $\mathrm{B}$ showed an $\mathrm{IC}_{50}$ of $60.5 \mathrm{nM}$ and $1.09 \mu \mathrm{M}$ respectively. Thus the marmycin A proved to be 18 times more potent in exhibiting cytotoxicity, than marmycin B. Further evaluation of in vitro cytotoxicity against 12 human tumor cell lines (breast, prostate, colon, lung, leukemia), revealed marmycin $\mathrm{A}$ to be potent, showing a mean $\mathrm{IC}_{50}$ value of $0.022 \mu \mathrm{M}$ while marmycin $\mathrm{B}$ was significantly less potent with a mean $\mathrm{IC}_{50}$ value of $3.5 \mu \mathrm{M}$ (Martin et al. 2007). Mansouramycins are a new class of compounds belonging to isoquinoline quinones. Mansouramycin A was isolated from Streptomyces sp. Mei37 from North Sea coast, Germany. Various mansouramycins extracted from this species are mansouramycin A (7-methylamino3,4-dimethylisoquinoline-5,8-dione),

mansouramycin B (6-chloro-3-methylisoquinoline5,8-dione), mansouramycin C (3-carbomethoxy-7methylaminoisoquinoline-5,8-dione),

mansouramycin D (3-(1H-indole-3yl)-7methylaminoisoquinoline-5,8-dione). Different mansouramycins are tested against the 36 cancer cell lines. Mansouramycin C dark red in color, showed highest cytotoxic action compared with other mansouramycis. When tested on 36 different cancer cell lines it exhibited action against 10 cell lines (T-24, SF-268, LXFA629L, MEXF 520L, OVCAR-3, RXF944L and UXF1138L), with inhibition concentrations ranging from 0.008 to $0.02 \mu \mathrm{M}$ (Hawas et al. 2009). Streptomyces sp. NTK 227, a strain isolated from Atlantic ocean sediment, was reported to produce secondary metabolite namely albidopyrone. The pyronecontaining secondary metabolite exhibited cytotoxic activity by moderately inhibiting protein tyrosine phosphatase B (Hohmann et al. 2009a).

Antitumor compound tartrolon $\mathrm{D}$, which belong to a group of macrodiolides, was isolated from the marine actinomycete Streptomyces sp. MDG-0417-069 from the east coast of Madagaskar at a depth of $30 \mathrm{~m}$. These dimers, with two polyketide chains, had a whitish color and exhibited potent effect on cancer cell lines A549 (lung carcinoma), HT-29 (colorectal carcinoma), and MDA-MB-231 (breast adenocarcinoma) (Pérez et al. 2009). Five bipyridine alkaloids named as caerulomycin $\mathrm{F}$, caerulomycin $\mathrm{G}$, caerulomycin $\mathrm{H}$, caerulomycin $\mathrm{I}$, caerulomycin $\mathrm{J}$, and one phenylpyrideine alkaloids named caerulomycin $\mathrm{K}$ were isolated from actinomycetes species Actinoalloteichus cyanogriseus WH1-2216-6 which showed cytotoxic effect on cancerous cell lines HL-60 (human promyelocytic leukemia), K562, KB (human epidermoid carcinoma of oral cavity) and A549 cell lines. The strain WH1-2216-6 was isolated from marine sediments collected from the seashore of Weihai, China. Analogous of caerulomycins showed antibiotic action against Escherichia coli, Aerobacter aerogenes, and Candida albicans at minimum inhibitory concentrations ranging from 9.7 to $38.6 \mu \mathrm{M}$ (Fu et al. 2011a). Four novel bipyridine cyclic glycosides namely cyanogrisides $\mathrm{A}, \mathrm{B}, \mathrm{C}$ and $\mathrm{D}$, were isolated from the actinomycete Actinoalloteichus cyanogriseus WH1-2216-6 derived from sediment collected from seashore of Weihai, China. Cyanogrisides A exhibited moderate cytotoxicity 
against K562, KB, MCF-7 cell lines with $\mathrm{IC}_{50}$ values of $1.2,4.7,9.8 \mu \mathrm{M}$ while cyanogrisides $\mathrm{C}$ exhibited cytotoxicity against K562 and KB cells with $\mathrm{IC}_{50}$ values of 0.73 and $4.7 \mu \mathrm{M}$ (Fu et al. 2011b).

\section{Peptides}

Table 2 represents the list of compounds from marine actinobacteria with peptides as chemical structure.

Table 2- Compounds with peptides as chemical structure

\begin{tabular}{|c|c|c|c|c|c|}
\hline Compound & Source & Organism & Family & Cancer & Reference \\
\hline Mechercharmycins & $\begin{array}{l}\text { Mecherchar } \\
\text { in Palau } \\
\text { (North } \\
\text { Pacific } \\
\text { ocean). }\end{array}$ & $\begin{array}{l}\text { Thermoactinomyces } \\
\text { sp. YM3-251 }\end{array}$ & Thermoactinomycetaceae & $\begin{array}{l}\text { Human } \\
\text { leukemia, } \\
\text { Human lung } \\
\text { cancer }\end{array}$ & $\begin{array}{l}\text { Kanoh et } \\
\text { al. } 2005\end{array}$ \\
\hline Lucentamycins & $\begin{array}{l}\text { Little San } \\
\text { Salvador, } \\
\text { Bahamas }\end{array}$ & $\begin{array}{l}\text { Nocardiopsis } \\
\text { lucentensis } \\
\text { strain CNR-712 }\end{array}$ & Nocardiopsaceae & $\begin{array}{l}\text { Human colon } \\
\text { carcinoma }\end{array}$ & $\begin{array}{l}\text { Cho et al. } \\
2007\end{array}$ \\
\hline Piperazimycins & $\begin{array}{l}\text { Island of } \\
\text { Guam }\end{array}$ & $\begin{array}{l}\text { Streptomyces sp. } \\
(C N Q-593)\end{array}$ & Streptomyceteceae & $\begin{array}{l}\text { Human colon } \\
\text { carcinoma }\end{array}$ & $\begin{array}{l}\text { Miller et } \\
\text { al. } 2007\end{array}$ \\
\hline Proximicins & $\begin{array}{l}\text { Sea of } \\
\text { Japan and } \\
\text { Raune } \\
\text { Fjord } \\
\text { (Norway) }\end{array}$ & $\begin{array}{l}\text { Verrucosispora sp. } \\
\text { AB-18-032; } \\
\text { Verrucosispora } \\
\text { strain } M G-37\end{array}$ & Micromonosporaceae & $\begin{array}{l}\text { Gastric } \\
\text { adenocarcinoma, } \\
\text { Hepatocellular } \\
\text { carcinoma, } \\
\text { Breast } \\
\text { adenocarcinoma }\end{array}$ & $\begin{array}{l}\text { Riedlinger } \\
\text { et al. } \\
2004 \text {; } \\
\text { Fiedler et } \\
\text { al. 2008; } \\
\text { Schneider } \\
\text { et al. 2008 }\end{array}$ \\
\hline Cyclomarins & $\begin{array}{l}\text { Mission } \\
\text { Bay, } \\
\text { California } \\
\text { and Palau }\end{array}$ & $\begin{array}{l}\text { Streptomycete } \\
\text { strain CNB-982, } \\
\text { Salinispora } \\
\text { arenicola } \text { CNS-205 }\end{array}$ & $\begin{array}{l}\text { Streptomyceteceae, } \\
\text { Micromonosporaceae }\end{array}$ & $\begin{array}{l}\text { Human colon } \\
\text { carcinoma }\end{array}$ & $\begin{array}{l}\text { Renner et } \\
\text { al.1999; } \\
\text { Schultz et } \\
\text { al. } 2008\end{array}$ \\
\hline Arenamides & $\begin{array}{l}\text { Great } \\
\text { Astrolab } \\
\text { Reef in } \\
\text { Kandavu } \\
\text { Island } \\
\text { chain, Fiji }\end{array}$ & $\begin{array}{l}\text { Salinispora } \\
\text { arenicola } \\
\text { CNT-088 }\end{array}$ & Micromonosporaceae & $\begin{array}{l}\text { Human colon } \\
\text { carcinoma }\end{array}$ & $\begin{array}{l}\text { Asolkar et } \\
\text { al. } 2009\end{array}$ \\
\hline
\end{tabular}

Peptides, the polymers of amino acids, are synthesized by non-ribosomal peptide synthetases (NRPS). NRPSs catalyse the condensation of aminoacyl-AMP to produce different peptides which are modified further by activities such as epimerization, methyltransferase, reductase or oxidase.

Thermoactinomyces sp. YM3-251 was isolated from sea mud collected at Mecherchar in the Republic of Palau (North Pacific ocean). The strain produced a new cytotoxic substance named mechercharmycin A which are cyclic peptide-like compound, bearing four oxazoles and a thiazole, and merchercharmycin B which are linear peptides. Mechercharmycin A exhibited strong inhibitory activity against Jurkat cells (human leukemia) and A549 cells. Mechercharmycin B did not exhibit antitumor activity against the cell lines. These results indicate the essentiality of the cyclic structure for the antitumor activity exhibited by mechercharmycin A (Kanoh et al. 2005). Four new structurally unique peptides namely Lucentamycins (A-D), containing 3-methyl-4-ethylideneproline, were produced by Nocardiopsis lucentensis CNR712. The strain was isolated from the sediments of a shallow saline pond from the island of Little San Salvador, in the Bahamas. The only structural differences between these compounds, accounted to the presence of phenyl and indole rings in Lucentamycin A and B, and absence of the moieties in Lucentamycin $\mathrm{C}$ and $\mathrm{D}$. In vitro cytoxicity analysis of Lucentamycins A and B showed potent cytotoxicity against $\mathrm{HCT}-116$ cell line with $\mathrm{IC}_{50}$ values of 0.20 and $11 \mu \mathrm{M}$, respectively, whereas lucentamycins $\mathrm{C}$ and $\mathrm{D}$ were not cytotoxic against HCT-116 cell line. This indicates that the aromatic 
ring present is essential for the biological activity of this class of compounds (Cho et al. 2007).

Streptomyces sp. CNQ-593 was isolated from a sediment sample collected at a depth of $20 \mathrm{~m}$ near the island of Guam. CNQ-593, produced three potent cancer cell cytotoxins, piperazimycins A-C which are cyclic hexadepsipeptides. Initially piperazimycins exhibited significant cytotoxity with an average $\mathrm{GI}_{50}$ of $76 \mathrm{ng} / \mathrm{mL}$ against HCT-116 cell line. In further evaluation, Piperazimycin A also showed potent biological activity against the oncologically diverse 60 cancer cell line panel at the National Cancer Institute, with mean $\mathrm{GI}_{50}$ value of $100 \mathrm{nM}$, TGI value of $300 \mathrm{nM}$ and $\mathrm{LC}_{50}$ value of $2 \mu \mathrm{M}$. Overall, piperazimycin A exhibited a nearly 3 -fold more potent activity against solid tumors (average $\mathrm{LC}_{50}$ value of $13.9 \mu \mathrm{M}$ ) than against the leukemia cell lines tested (average $\mathrm{LC}_{50}$ value of $31.4 \mu \mathrm{M}$ ). In solid tumors, piperazimycin A was most active against the melanoma, central nervous system, prostate cell lines. Piperazimycin A was also active against the colon cancer group, renal cancers, ovarian cancers, non-small cell lung cancers and breast cancers (Miller et al. 2007). A family of structure-related peptide metabolites, named proximicin $\mathrm{A}, \mathrm{B}$, and $\mathrm{C}$ were reported to be produced by marine actinomycete Verrucosispora sp. AB-18-032 , Verrucosispora sp. MG-37, isolated from sediment collected from the Sea of Japan at a depth of $289 \mathrm{~m}$, and Raune Fjord (Norway) at a depth of $250 \mathrm{~m}$, respectively (Riedlinger et al. 2004; Fiedler et al. 2008). Schneider et al. (2008) reported the structure of proximicins as a unknown $\gamma$-amino acid 4aminofuran-2-carboxylic acid. Proximicins A,B and $\mathrm{C}$ exhibited significantly higher growth inhibitory activity towards gastric adenocarcinoma AGS with $\mathrm{GI}_{50}$ value of $0.6,1.5,0.25 \mu \mathrm{M}$, respectively and $\mathrm{HepG} 2$ cell lines with $\mathrm{GI}_{50}$ value of $0.82,9.5,0.78 \mu \mathrm{M}$, respectively, whereas MCF7 cell lines were found to be less sensitive to proximicins A,B and C. Moreover studies on the effect of proximicins on the cell cycle, revealed an arrest of AGS cells in G0/G1 and an increase in the levels of p53 and p21.

New cyclic heptapeptides, cyclomarins A-C (1-3), were isolated from extracts of a cultured marine Streptomyces sp. CNB-982, isolated from a sediment sample collected in Mission Bay, California and cyclomarin D from Salinispora arenicola CNS-205, isolated from Palau. (Renner et al.1999; Schultz et al. 2008). The major metabolite, cyclomarin A was found to be cytotoxic in vitro towards cancer cells with mean $\mathrm{IC}_{50}$ value of 2.6 $\mu \mathrm{M}$ against a panel of human cancer cell lines (Renner et al. 1999) and cyclomarin D displayed moderate cytotoxicity against HCT-116 cell lines with an $\mathrm{IC}_{50}$ value of $2 \mu \mathrm{g} / \mathrm{mL}$ (Schultz et al. 2008). The extract of a marine actinomycete strain Salinispora arenicola CNT-088 yielded three new cyclohexadepsipeptides, arenamides A-C. The strain was obtained from a marine sediment sample collected at a depth of $20 \mathrm{~m}$ off the Great Astrolab Reef, in the Kandavu Island chain, Fiji. Arenamides $\mathrm{A}$ and $\mathrm{B}$ exhibited weak in vitro cytotoxicity against HCT-116 cell lines with $\mathrm{IC}_{50}$ values of 13.2 and $19.2 \mu \mathrm{g} / \mathrm{mL}$, respectively. Arenamides were reported to be inhibitors of NF$\kappa \mathrm{B}$, the nuclear transcription factor, thus suppressing carcinogenesis. Stably transfected 293/ NF- $\kappa$ B -Luc human embryonic kidney cells, induced by treatment with tumor necrosis factor (TNF) were used to study the effect of arenamides on NF- $\kappa \mathrm{B}$ activity. Arenamides A and B blocked TNF-induced activation in a dose and time dependent manner with $\mathrm{IC}_{50}$ values of 3.7 and 1.7 $\mu \mathrm{M}$, respectively (Asolkar et al. 2009).

\section{Polyketide peptides}

Table 3 represents the list of compounds from marine actinobacteria with polyketide peptides as chemical structure.

Table 3- Compounds with polyketide peptides as chemical structure

\begin{tabular}{|c|c|c|c|c|c|}
\hline Compound & Source & Organism & Family & Cancer & Reference \\
\hline Salinosporamides & $\begin{array}{l}\text { Chub Cay, } \\
\text { Bahamas }\end{array}$ & $\begin{array}{l}\text { Salinospora } \\
\text { strain } \\
\text { CNB-392 }\end{array}$ & Micromonosporaceae & $\begin{array}{l}\text { Human colon } \\
\text { carcinoma }\end{array}$ & $\begin{array}{l}\text { Feling et al. } \\
2003\end{array}$ \\
\hline Lajollamycin & $\begin{array}{l}\text { Scripps } \\
\text { Canyon, } \\
\text { La Jolla, } \\
\text { California }\end{array}$ & $\begin{array}{l}\text { Streptomyces } \\
\text { nodosus } \\
\text { NPS007994 }\end{array}$ & Streptomyceteceae & Melanoma & $\begin{array}{l}\text { Manam et } \\
\text { al. } 2005\end{array}$ \\
\hline
\end{tabular}

Type I PKS and NRPSs combine to catalyse and allows the formation of the hybrid polyketidepeptides.

Salinospora CNB-392 was isolated from a sediment sample collected at a depth of about $1 \mathrm{~m}$ from a mangrove environment in Chub Cay, 
Bahamas. The strain CNB-392 produced the chemically unique and highly bioactive metabolite salinosporamide A, which inhibited 20S proteasome. The compound was highly cytotoxic in vitro toward HCT-116 cell lines ( $\mathrm{IC}_{50}$ ca. $80 \mathrm{ngmL}^{-}$ $\left.{ }^{1}\right)$ and the metabolite also displayed selective activity against NCI 60 cell line panel in which greatest potency was observed against NCI-H226 non-small cell lung cancer, SF-539 CNS cancer, SK-MEL-28 melanoma, and MDA-MB-435 breast cancer (all with $\mathrm{LC}_{50}$ values less than $10 \mathrm{~nm}$ ). Salinosporamide A inhibited proteasomal chymotrypsin like proteolytic activity, when tested against purified 20S proteasome (Calbiochem, cat.no. 539158) with an $\mathrm{IC}_{50}$ value of $1.3 \mathrm{~nm}$ (Feling et al. 2003). A nitro-tetraene spiro- $\beta$-lactone- $\gamma$ lactam antibiotic, lajollamycin, was produced by Streptomyces nodosus NPS007994 isolated from a marine sediment collected in Scripps Canyon, La Jolla, California. The polyketide-peptide was reported to inhibit the growth of murine melanoma cell line B16-F10, with an $\mathrm{EC}_{50}$ value of $9.6 \mu \mathrm{M}$ (Manam et al. 2005).

\section{Isoprenoids}

Table 4 represents the list of compounds from marine actinobacteria with isoprenoids as chemical structure.

Table 4- Compounds with isoprenoids as chemical structure

\begin{tabular}{|c|c|c|c|c|c|}
\hline Compound & Source & Organism & Family & Cancer & Reference \\
\hline Altemicidin & Gamo, Japan & $\begin{array}{l}\text { Streptomyces } \\
\text { sioyaensis } \\
\text { SA-1758 }\end{array}$ & Streptomyceteceae & $\begin{array}{l}\text { Lymphoid } \\
\text { leukemia, } \\
\text { Carcinoma }\end{array}$ & $\begin{array}{l}\text { Takahashi } \\
\text { et al. 1989a; } \\
\text { Takahashi } \\
\text { et al. 1989b }\end{array}$ \\
\hline Neomarinones & $\begin{array}{l}\text { Lagoon, } \\
\text { North of San } \\
\text { Diego, } \\
\text { California }\end{array}$ & $\begin{array}{l}\text { Actinomycete } \\
\text { isolate } \\
\text { CNH-099 }\end{array}$ & Actinomycetaceae & $\begin{array}{l}\text { Human colon } \\
\text { carcinoma }\end{array}$ & $\begin{array}{l}\text { Hardt et al. } \\
2000 ; \\
\text { Kalaitzis et } \\
\text { al. } 2003\end{array}$ \\
\hline Glaciapyrroles & Alaska & $\begin{array}{l}\text { Streptomyces } \\
\text { sp. } \\
\text { (NPS008187) }\end{array}$ & Streptomyceteceae & $\begin{array}{l}\text { Colorectal } \\
\text { adenocarcinoma, } \\
\text { Melanoma }\end{array}$ & $\begin{array}{l}\text { Macherla et } \\
\text { al. } 2005\end{array}$ \\
\hline $\begin{array}{l}\text { Drimentine G; } \\
\text { Indotertine B }\end{array}$ & $\begin{array}{l}\text { Guangdong } \\
\text { province }\end{array}$ & $\begin{array}{l}\text { Streptomyces } \\
\text { sp. CHQ-64 }\end{array}$ & Streptomyceteceae & $\begin{array}{l}\text { Human colon } \\
\text { cancer, } \\
\text { Human } \\
\text { hepatocellular } \\
\text { carcinoma, } \\
\text { Human lung } \\
\text { cancer, } \\
\text { Human ovarian } \\
\text { carcinoma; }\end{array}$ & $\begin{array}{l}\text { Che et al. } \\
\text { 2012; Che } \\
\text { et al. } 2013\end{array}$ \\
\hline
\end{tabular}

Isoprenoids forms the largest family, comprising a large number of industrially useful compounds. Isoprenoids are synthesized from the five-carbon precursor molecule isopentenyl diphosphates (IPP) via 2-C-methyl-Derythritol 4-phosphate (MEP) pathway.

Streptomyces sioyaensis SA-1758 was isolated from sea mud collected at Gamo, Miyagi Prefecture, Japan. The strain SA-1758 produced a monoterpene-alkaloid, altemicidin (Takahashi et al. 1989a). The compound strongly inhibited the growth of L1210 and carcinoma IMC cell lines with $\mathrm{IC}_{50}$ values of 0.84 and $0.82 \mu \mathrm{g} / \mathrm{mL}$, respectively
(Takahashi et al. 1989b). Neomarinones are sesquiterpenoid naphtho-quinones with a mixed polyketide-terpenoid origin (Pathirana et al. 1992). A novel marine actinomycete isolate $\mathrm{CNH}-099$ found in a sediment sample collected at $1 \mathrm{~m}$ in Batiquitos Lagoon, North of San Diego, California, produced several cytotoxic metabolites related to marinone, such as neomarinone, isomarinone, hydroxydebromomarinone and methoxydebromomarinone. These compounds exhibited moderate in vitro cytotoxicity $\left(\mathrm{IC}_{50}\right.$ ca. 8 $\mu \mathrm{g} / \mathrm{mL})$ against HCT-116 cells. Furthermore, neomarinone generated a mean $\mathrm{IC}_{50}$ value of $10 \mu \mathrm{M}$ 
in the NCI's 60 cancer cell line panel (Hardt et al. 2000; Kalaitzis et al. 2003). Glaciapyrroles (pyrrolosesquiterpenes) were found to be produced by Streptomyces sp. NPS008187 that was isolated from a marine sediment collected in Alaska. Glaciapyrroles inhibited both HT-29 and B16-F10 tumor cell growth (Macherla et al. 2005). Actinomycete strain CNQ-525, was isolated from a sediment sample derived from a depth of $152 \mathrm{~m}$ near La Jolla, California. The culture broth of the strain yielded three new chlorinated dihydroquinones and a previously reported analogue. These chlorine-containing terpenoid dihydroquinones possessed significant cytoxicity against HCT-116 cell lines (Soria-Mercado et al. 2005).

Streptomyces sp. CHQ-64 was isolated from the reeds rhizosphere soil of mangrove conservation area in Guangdong province, China. The culture broth yielded indotertine $\mathrm{A}$ and $\mathrm{B}$, hybrid isoprenoid with a condensed pentacyclic skeleton, and two related compounds drimentines F, G and H. Drimentines $G$ showed potent cytotoxicity against HCT-8, (human colon cancer cell line), Bel7402 (human hepatocellular carcinoma cell line), A549 and A2780 (human ovarian carcinoma cell line), with $\mathrm{IC}_{50}$ values of $2.81,1.38,1.01$, and 2.54 $\mu \mathrm{M}$, respectively. Indotertine $\mathrm{B}$ exhibited best cytotoxic activities against the HCT-8 and A549 cell lines with $\mathrm{IC}_{50}$ values of 6.96 and $4.88 \mu \mathrm{M}$, respectively (Che et al. 2012; Che et al. 2013).

\section{Indolocarbazoles}

Table 5 represents the list of compounds from marine actinobacteria with indolocarbazoles as chemical structure.

Table 5- Compounds with indolocarbazoles as chemical structure

\begin{tabular}{|c|c|c|c|c|c|}
\hline Compound & Source & Organism & Family & Cancer & Reference \\
\hline ZHD-0501 & $\begin{array}{l}\text { Jiaozhou Bay, } \\
\text { China }\end{array}$ & $\begin{array}{l}\text { Actinomadura } \\
\text { sp. } 007\end{array}$ & Thermomonosporaceae & $\begin{array}{l}\text { Human lung } \\
\text { adenocarcinoma, } \\
\text { Hepatocarcinoma, } \\
\text { Pro-myelocytic } \\
\text { leukemia }\end{array}$ & $\begin{array}{l}\text { Han et al. } \\
2005\end{array}$ \\
\hline $\begin{array}{l}\mathrm{N} \text {-formyl } \\
\text { staurosporine, } \\
\mathrm{N} \text {-formyl } \\
\text { staurosporine, } \\
\text { Selina- } \\
\text { 4(14),7(11)- } \\
\text { diene-8,9-diol }\end{array}$ & $\begin{array}{l}\text { Jiaozhou Bay, } \\
\text { Qindao, China }\end{array}$ & $\begin{array}{l}\text { Streptomyces } \\
\text { sp } \\
\text { isolate QD518 }\end{array}$ & Streptomyceteceae & $\begin{array}{l}\text { Bladder, CNS, } \\
\text { Colon, Gastric, } \\
\text { Head and Neck, } \\
\text { Lung, Mammary, } \\
\text { Ovarian, } \\
\text { Pancreatic, } \\
\text { Prostate, Renal } \\
\text { cancer }\end{array}$ & Wu et al. 2006 \\
\hline $\begin{array}{l}\text { K252c, } \\
\text { Arcyriaflavin A }\end{array}$ & $\begin{array}{l}\text { Coast of } \\
\text { Qingdao, } \\
\text { China }\end{array}$ & $\begin{array}{l}\text { Actinomycete } \\
\text { strain } \\
\text { Z2039-2 }\end{array}$ & Actinomycetaceae & $\begin{array}{l}\text { Human chronic } \\
\text { myelogenous } \\
\text { leukemia }\end{array}$ & Liu et al. 2007 \\
\hline Albidopyrone & $\begin{array}{l}\text { Atlantic ocean } \\
\text { sediment }\end{array}$ & $\begin{array}{l}\text { Streptomyces } \\
\text { sp. } \\
\text { NTK } 227\end{array}$ & Streptomyceteceae & & $\begin{array}{l}\text { Hohmann et } \\
\text { al. 2009a }\end{array}$ \\
\hline Chromomycin & $\begin{array}{l}\text { Bijiatuan, } \\
\text { China }\end{array}$ & $\begin{array}{l}\text { Streptomyces } \\
\text { sp. } \\
\text { WBF16 }\end{array}$ & Streptomyceteceae & $\begin{array}{l}\text { Human gastric } \\
\text { cancer, } \\
\text { Human liver } \\
\text { hepatocellular } \\
\text { carcinoma, } \\
\text { Human colon } \\
\text { cancer, } \\
\text { Human lung } \\
\text { adenocarcinoma }\end{array}$ & Lu et al. 2012 \\
\hline Streptokordin & $\begin{array}{l}\text { Ayu Trough, } \\
\text { Pacific ocean }\end{array}$ & $\begin{array}{l}\text { Streptomyces } \\
\text { sp. } \\
\text { KORDI-3238 }\end{array}$ & Streptomyceteceae & $\begin{array}{l}\text { Human breast } \\
\text { cancer, Human } \\
\text { renal cancer, }\end{array}$ & $\begin{array}{l}\text { Jeong et al. } \\
2006\end{array}$ \\
\hline
\end{tabular}




\begin{tabular}{|c|c|c|c|c|c|}
\hline & & & & $\begin{array}{l}\text { Human skin } \\
\text { cancer, } \\
\text { Human leukemia }\end{array}$ & \\
\hline $\begin{array}{l}\text { Mansouramycin } \\
\text { C }\end{array}$ & $\begin{array}{l}\text { Jade Bay, } \\
\text { southern } \\
\text { German North } \\
\text { Sea coast }\end{array}$ & $\begin{array}{l}\text { Streptomyces } \\
\text { sp. } \\
\text { Isolate } \\
\text { (Mei37) }\end{array}$ & Streptomyceteceae & $\begin{array}{l}\text { Non-small cell } \\
\text { lung cancer, } \\
\text { Melanoma, } \\
\text { Breast cancer, } \\
\text { Prostate cancer }\end{array}$ & $\begin{array}{l}\text { Hawas et al. } \\
2009\end{array}$ \\
\hline $\begin{array}{l}\text { Usabamycin } \mathrm{A}- \\
\mathrm{C}\end{array}$ & $\begin{array}{l}\text { Usa Bay, } \\
\text { Kochi } \\
\text { Prefecture, } \\
\text { Japan }\end{array}$ & $\begin{array}{l}\text { Streptomyces } \\
\text { sp. } \\
\text { NPS853 }\end{array}$ & Streptomyceteceae & $\begin{array}{l}\text { Human epithelial } \\
\text { carcinoma }\end{array}$ & $\begin{array}{l}\text { Sato et al. } \\
2011\end{array}$ \\
\hline $\begin{array}{l}1(10- \\
\text { aminodecyl) } \\
\text { Pyridinium }\end{array}$ & Bay of Bengal & $\begin{array}{l}\text { Amycolatopsis } \\
\text { alba } \\
\text { (DVR D4) }\end{array}$ & Pseudonocardiaceae & $\begin{array}{l}\text { Cervix cancer, } \\
\text { Brain cancer }\end{array}$ & $\begin{array}{l}\text { Dasari et al. } \\
2012\end{array}$ \\
\hline $\begin{array}{l}\text { Stretocarbazoles } \\
\text { A,B }\end{array}$ & $\begin{array}{l}\text { Sanya, Hainan } \\
\text { Province,China }\end{array}$ & $\begin{array}{l}\text { Streptomyces } \\
\text { sp. } \\
\text { strain FMA }\end{array}$ & Streptomyceteceae & $\begin{array}{l}\text { Human } \\
\text { promyelocytic } \\
\text { leukemia, } \\
\text { Human alveolar } \\
\text { adenocarcinoma }\end{array}$ & Fu et al. 2012 \\
\hline $\begin{array}{l}\text { 1-ethyl- } \beta \text { - } \\
\text { carboline-3- } \\
\text { carboxylic acid, } \\
\text { 1-methyl } \\
\text { indole-3- } \\
\text { carboxamide, }\end{array}$ & $\begin{array}{l}\text { Khuean } \\
\text { Srinagarindra } \\
\text { National Park, } \\
\text { Kanchanaburi } \\
\text { Province, } \\
\text { Thailand }\end{array}$ & $\begin{array}{l}\text { Actinomadura } \\
\text { sp. BCC } \\
24717\end{array}$ & Thermomonosporaceae & $\begin{array}{l}\text { Human } \\
\text { epidermoid } \\
\text { carcinoma of oral } \\
\text { cavity, Human } \\
\text { small cell lung } \\
\text { cancer }\end{array}$ & $\begin{array}{l}\text { Kornsakulkarn } \\
\text { et al. } 2013\end{array}$ \\
\hline $\begin{array}{l}\text { Spiroindimicins } \\
\text { A-D, } \\
\text { Indimicin B }\end{array}$ & $\begin{array}{l}\text { South China } \\
\text { Sea and Indian } \\
\text { ocean }\end{array}$ & $\begin{array}{l}\text { Streptomyces } \\
\text { sp. SCSIO } \\
03032\end{array}$ & Streptomyceteceae & $\begin{array}{l}\text { Human } \\
\text { lymphoblastic } \\
\text { leukemia, Murine } \\
\text { melanoma, } \\
\text { Human lung } \\
\text { cancer, Human } \\
\text { liver cancer, } \\
\text { Human breast } \\
\text { cancer }\end{array}$ & $\begin{array}{l}\text { Zhang et al. } \\
2014\end{array}$ \\
\hline
\end{tabular}

Indolocarbazoles are distinct family of compounds displaying wide range of biological activities such as antitumor, antibacterial and antifungal. These form unique class of compounds with characteristic structure of indolo[2,3-a]pyrrolo[3,4$c$ carbazole as the core which is derived from two molecules of tryptophan.

Actinomadura sp. 007, was isolated from sea sediment sample collected in Jiaozhou Bay, China. The culture broth of the strain yielded a staurosporine analog, ZHD-0501. The compound exhibited cytotoxic activity against A549, BEL-
7402, and pro-myelocytic leukemia HL60 cancer cell lines, P388 cells and mouse mammary cancer tsFT210 cells (Han et al. 2005). Wu et al. (2006) reported the isolation of Streptomyces sp. QD518 from the Jiaozhou Bay of Qindao, China. Among the metabolites produced by the actinobacteria, Nformylstaurosporine, N-carboxamidostaurosporine, selina-4(14),7(11)-diene-8,9-diol exhibited in vitro anticancer activity against 37 human tumor cell lines derived from solid human tumors comprising bladder, central nervous system, colon, gastric, head and neck, lung, mammary, 
ovarian, pancreatic, prostate and renal cancers, as well as cell lines established from human melanoma, pleuramesothelioma and the uteri body. Indolocarbazole alkaloids, namely $\mathrm{K} 252 \mathrm{c}$ and arcyriaflavin A were isolated from actinomycete strain Z2039-2, collected on the coast of Qingdao. Cytotoxic effects of the two compounds against K562 cell lines have been evaluated. The indolocarbazoles has also exhibited significant apoptic activity (Liu et al. 2007). Streptomyces sp. NTK 227, a strain isolated from Atlantic ocean sediment, was reported to produce secondary metabolite namely albidopyrone. The pyrone containing secondary metabolite exhibited cytotoxic activity by moderately inhibiting protein tyrosine phosphatase B (Hohmann et al. 2009a).

A marine-derived actinomycete, identified as Streptomyces sp. WBF16, was isolated from sea sediments located in Bijiatuan, in the city of Weihai, China. Chromomycin A2, chromomycin $\mathrm{A} 3$, and chromomycin $\mathrm{B}$ which are a family of aureolic acids are found to be produced by WBF16. Chromomycin (A2, A3, and B) exhibited cytotoxic activity against human gastric cancer cell line (SGC7901), HepG2, A549, HCT116, human ovarian cancer cell line (COC1), while Chromomycin B alone exhibited strong cytotoxic activity against Human Umbilical Vein Endothelial Cells (HUVEC) (Lu et al. 2012). A new cytotoxic compound, streptokordin was reported to be produced by Streptomyces sp. KORDI-3238, which was isolated from a deep-sea sediment sample collected at Ayu Trough, in the western Pacific ocean. In vitro cytotoxicity against several human cancer cell lines such as MDA-MB-231, HCT 15, human prostate cancer (PC-3), human lung cancer (NCI-H23), human renal cancer (ACHN), human skin cancer (LOXIMVI), K562 proved that streptokordin exhibited significant cytotoxicity (Jeong et al. 2006). Hawas et al. (2009) reported the isolation of Streptomyces sp. Mei37 from the muddy sediment of Jade Bay on the southern German North Sea coast, which produced five isoquinolinequinones among which mansouramycin $\mathrm{C}$ as the main quinone. In vitro cytotoxicity analysis of the derivatives against 36 human tumor cell lines indicated significant cytotoxicity with pronounced selectivity for non small cell lung cancer, breast cancer, melanoma, and prostate cancer cells.

New anthramycin type analogues, usabamycin A, B and C are produced by Streptomyces sp. NPS853, isolated from a marine sediment sample collected at a depth of 20 m near Usa Bay, Kochi Prefecture, Japan. The usabamycins (A-C) exhibited weak cytotoxic activity against HeLa cells in vitro, with IC $_{50}$ values of $106.6 \mu \mathrm{M}, 103.5 \mu \mathrm{M}, 101.9 \mu \mathrm{M}$ respectively, and selective inhibition of serotonin (5-hydroxytrypamine) 5-HT2B uptake (Sato et al. 2011). Amycolatopsis alba (DVR D4) was isolated from the sediments from Bay of Bengal (NTPC area, Visakhapatnam, India). The strain produced a cytotoxic compound identified as 1(10aminodecyl) pyridinium salt antibiotic. The compound exhibited significant cytotoxic activity profile against cancer cell lines of HeLa, MCF-7 and brain (U87MG) in vitro (Dasari et al. 2012). Streptomyces sp. strain FMA was isolated from a mangrove soil collected in Sanya, Hainan Province of China. The ethyl acetate extracts contained two novel indolocarbazoles, streptocarbazoles $\mathrm{A}$ and $\mathrm{B}$, which exhibited potent cytotoxicity against HL-60 and A549 cell lines (Fu et al. 2012).

Actinomadura sp. BCC 24717 was isolated from soil, collected at Khuean Srinagarindra National Park, Kanchanaburi Province, Thailand. The culture broth yielded four new $\beta$-carbolines namely methyl 1-(2-methyl carbamate)ethyl- $\beta$-carboline3 -carboxylate, methyl 1-(propionic acid)- $\beta$ carboline-3-carboxylate, methyl 1-(methyl propionate)- $\beta$-carboline-3-carboxylate, 1 -ethyl- $\beta$ carboline-3-carboxylic acid, and two new indoles namely 1-hydroxymethylindole-3-carboxylic acid, 1-methyl indole-3-carboxamide. The compounds, 1 -ethyl- $\beta$-carboline-3-carboxylic acid and 1-methyl indole-3-carboxamide exhibited cytotoxicity to Vero African green monkey kidney cell lines $\left(\mathrm{IC}_{50}\right.$ $35.91 \mathrm{mg} / \mathrm{mL}$ ), while the compound, 1 -vinyl- $\beta$ carboline-3-carboxylic acid was moderately active against $\mathrm{KB}$ cells, human small cell lung cancer (NCI-H187), and Vero cells ( $\mathrm{IC}_{50}$ 14.50-23.88 $\mathrm{mg} / \mathrm{mL}$ ) (Kornsakulkarn et al. 2013). Spiroindimicins A-D, were produced by the culture extract of Streptomyces sp. SCSIO 03032 which was isolated from South China Sea and Indian ocean. The bisindole alkaloids were evaluated for cytotoxicity against various cell lines. Spiroindimicin B exhibited moderate cytotoxic activities against human lymphoblastic leukemic cell line (CCRF-CEM), B16 and human lung cancer cell line (H460) with $\mathrm{IC}_{50}$ values of 4, 5, and 12 $\mu \mathrm{g} / \mathrm{mL}$, respectively. Spiroindimicin $\mathrm{C}$ showed cytotoxicity against $\mathrm{HepG} 2$ and $\mathrm{H} 460$ with $\mathrm{IC}_{50}$ values of 6 and $15 \mu \mathrm{g} / \mathrm{mL}$. Spiroindimicin D showed moderate inhibitory effects against HepG2, B16, and H460 (Zhang et al. 2012). The strain 
SCSIO 03032 was also reported to produce five new bisindole alkaloids, indimicins $\mathrm{A}-\mathrm{E}$ and lynamicins $F$ and $G$. Indimicin $B$ exhibited cytotoxicity against MCF-7 cell lines with $\mathrm{IC}_{50}$ value $10.0 \mu \mathrm{M}$ (Zhang et al. 2014).

\section{Other chemical structures}

Table 6 represents the list of compounds from marine actinobacteria with other chemical structures.

Table 6- Compounds with other chemical structure

\begin{tabular}{|c|c|c|c|c|c|}
\hline Compound & Source & Organism & Family & Cancer & Reference \\
\hline Benzastatins & $\begin{array}{l}\text { Sokcho- } \\
\text { city, } \\
\text { Kangwon- } \\
\text { do, Korea }\end{array}$ & $\begin{array}{l}\text { Streptomyces } \\
\text { nitrosporeus } \\
30643\end{array}$ & Streptomyceteceae & Neuroblastoma & $\begin{array}{l}\text { Kim et al. } \\
1996\end{array}$ \\
\hline $\begin{array}{l}\text { Chandrananimycin } \\
\text { A,B,C, } \\
\text { Questiomycin A, } \\
\text { N- } \\
\text { acetylquestiomycin, } \\
\text { Iodinin and } \\
\text { 1,6-phenazinediol }\end{array}$ & $\begin{array}{l}\text { Jiaozhou } \\
\text { Bay in } \\
\text { China }\end{array}$ & $\begin{array}{l}\text { Actinomadura sp. } \\
\text { isolate M048 }\end{array}$ & Thermomonosporaceae & $\begin{array}{l}\text { Human colon } \\
\text { carcinoma, } \\
\text { Melanoma, } \\
\text { Human lung } \\
\text { carcinoma, } \\
\text { Human breast } \\
\text { carcinoma, } \\
\text { Human kidney } \\
\text { tumor, Human } \\
\text { uterus cancer }\end{array}$ & $\begin{array}{l}\text { Maskey et } \\
\text { al. } 2003\end{array}$ \\
\hline Butenolides & $\begin{array}{l}\text { TaiPingJiao, } \\
\text { QingDao, } \\
\text { China }\end{array}$ & $\begin{array}{l}\text { Streptoverticillium } \\
\text { luteoverticillatum } \\
11014\end{array}$ & Streptomyceteceae & $\begin{array}{l}\text { Human } \\
\text { leukemia } \\
\text { Murine } \\
\text { lymphoma }\end{array}$ & $\begin{array}{l}\text { Li et al. } \\
2006\end{array}$ \\
\hline Bohemamine & $\begin{array}{l}\text { Island of } \\
\text { Guam }\end{array}$ & $\begin{array}{l}\text { Streptomyces sp. } \\
C N Q-583\end{array}$ & Streptomyceteceae & $\begin{array}{l}\text { Human colon } \\
\text { adenocarcinoma }\end{array}$ & $\begin{array}{l}\text { Bugni et } \\
\text { al. } 2006\end{array}$ \\
\hline Streptochlorin & $\begin{array}{l}\text { Ayajin Bay, } \\
\text { Korea }\end{array}$ & $\begin{array}{l}\text { Streptomyces sp. } \\
04 \mathrm{DH} 110\end{array}$ & Streptomyceteceae & $\begin{array}{l}\text { Human } \\
\text { leukemia }\end{array}$ & $\begin{array}{l}\text { Shin et al. } \\
2007\end{array}$ \\
\hline Streptopyrrolidine & Ayu Trough & $\begin{array}{l}\text { Streptomyces sp. } \\
\text { KORDI-3973 }\end{array}$ & Streptomyceteceae & & $\begin{array}{l}\text { Shin et al. } \\
2008 b\end{array}$ \\
\hline Caboxamycin & $\begin{array}{l}\text { Atlantic } \\
\text { ocean, } \\
\text { Canary } \\
\text { Islands }\end{array}$ & $\begin{array}{l}\text { Streptomyces sp. } \\
\text { NTK } 937\end{array}$ & Streptomyceteceae & $\begin{array}{l}\text { Human gastric } \\
\text { adenocarcinoma, } \\
\text { Hepaticellular } \\
\text { carcinoma, } \\
\text { Breast } \\
\text { carcinoma }\end{array}$ & $\begin{array}{l}\text { Hohmann } \\
\text { et al. } \\
2009 b\end{array}$ \\
\hline Ammosamides & $\begin{array}{l}\text { Bahamas } \\
\text { islands }\end{array}$ & $\begin{array}{l}\text { Streptomyces } \\
\text { strain } \\
\text { CNR-698 }\end{array}$ & Streptomyceteceae & $\begin{array}{l}\text { HCT-116 colon } \\
\text { carcinoma }\end{array}$ & $\begin{array}{l}\text { Hughes et } \\
\text { al. } 2009\end{array}$ \\
\hline Dermacozine & $\begin{array}{l}\text { Mariana } \\
\text { Trench } \\
\text { sediment }\end{array}$ & $\begin{array}{l}\text { Dermacoccus } \\
\text { abyssi sp. nov., } \\
\text { strains MT1.1 and } \\
\text { MR1.2, }\end{array}$ & Dermacoccaceae & $\begin{array}{l}\text { Human chronic } \\
\text { myelogenous } \\
\text { leukemia }\end{array}$ & $\begin{array}{l}\text { Abdel- } \\
\text { Mageed et } \\
\text { al. } 2010\end{array}$ \\
\hline $\begin{array}{l}\mathrm{N}-(2- \\
\text { hydroxyphenyl)-2- } \\
\text { phenazinamine }\end{array}$ & $\begin{array}{l}\text { Arctic } \\
\text { ocean }\end{array}$ & $\begin{array}{l}\text { Nocardia } \\
\text { dassonvillei BM- } \\
17\end{array}$ & Nocardiaceae & $\begin{array}{l}\text { Human liver } \\
\text { hepatocellular } \\
\text { carcinoma, } \\
\text { Human lung } \\
\text { adenocarcinoma, } \\
\text { Human colon } \\
\text { adenocarcinoma, } \\
\text { Human ovarian } \\
\text { cancer }\end{array}$ & $\begin{array}{l}\text { Gao et al. } \\
2012\end{array}$ \\
\hline
\end{tabular}

\section{Benzastatins}

Streptomyces nitrosporeus 30643 was isolated from the soil collected in Sokcho-city, Kangwon-do, 
Korea. The culture broth of the strain 30643 contained benzastatins, rare metabolites, which are free radical scavengers. Benzastatins A and B, have a aminobenzamide skeleton whereas benzastatins $C$ and $\mathrm{D}$ have a tetrahydroquinoline skeleton. Cytotoxicity analysis of benzastatins against neuroblastoma and retina hybrid cell line N18-RE105 showed that benzastatin $\mathrm{C}$ exhibited cytotoxicity with an $\mathrm{IC}_{50}$ value of $38.1 \mu \mathrm{M}$ (Kim et al. 1996).

\section{Chandrananimycin}

Actinomadura sp. isolate M048 was derived from the sediment collected from Jiaozhou Bay in China. The crude extract of the strain M048 yielded three novel antibiotics designated as chandrananimycin $\mathrm{A}, \mathrm{B}$ and $\mathrm{C}$, containing phenoxazinone chromophores and six known metabolites, namely iodinin, 1,6-phenazinediol, questiomycin A, Nacetylquestiomycin, genistein, daidzein. The compounds questiomycin A, Nacetylquestiomycin, Chandrananimycin A, B and $\mathrm{C}$ exhibited cytotoxicity with $\mathrm{IC}_{70}$ values down to $1.4 \mu \mathrm{g} / \mathrm{ml}$, against the human cell lines, CCL HT29 (colon carcinoma), MEXF 514L (melanoma), LXFA 526L (lung carcinoma), LXFL 529L (lung carcinoma), CNCL SF268, LCL H460, MACL MCF-7 (breast carcinoma), PRCL PC3M, RXF 631L (kidney tumor). Iodinin and 1,6phenazinediol showed antitumour activity against the human cell lines LXFA 629L and LXFL 529L (lung), MAXF 401NL, MEXF 462NL, RXF 944L and UXF 1138L (uterus) with $\mathrm{IC}_{50}$ values of 3.6 and $3.2 \mu \mathrm{g} / \mathrm{ml}$, respectively (Maskey et al. 2003).

\section{Butenolides}

The bacterial strain Streptoverticillium luteoverticillatum 11014 was isolated from underwater sediment collected off the coast of TaiPingJiao, QingDao, China. The fermentation extract of the strain yielded four known butenolides namely (4S)-4,10-dihydroxy-10-methyl-undec-2en-1,4-olide (compound 1), (4S)-4,10-dihydroxy10-methyl-dodec-2-en-1,4-olide (compound 2) and two diastereomeric (4S)-4,11-dihydroxy-10methyl-dodec-2-en-1,4-olides (compound 3 and 4). In vitro cytotoxicity analysis by SRB assay revealed that the compounds exhibited cytotoxicity at high concentrations against $\mathrm{K} 562$ cell lines ( $\mathrm{IC}_{50}$ values of $8.73,6.29$, and $1.05 \mu \mathrm{mol} / \mathrm{mL}$ ) and $\mathrm{P} 388$ cell lines ( $\mathrm{IC}_{50}$ values of $0.34,0.19$ and $0.18 \mu \mathrm{mol} / \mathrm{mL}$ ) (Li et al. 2006).

\section{Bohemamine}

Marine sediment sample collected from the island of Guam, was used to isolate the strain CNQ-583, identified as Streptomyces species. Pyrrolizidine alkaloids, bohemamine B (1), bohemamine C (2), and 5-chlorobohemamine $\mathrm{C} \mathrm{(3)}$ were isolated from the extract of the strain. The compounds were tested for inhibition of HCT-116 cell lines but were found to be inactive (Bugni et al. 2006). Zhang et al. (2003) reported that bohemamine and deoxybohemamine to be cell adhesion inhibitors based on LFA-1/ICAM-1 capable of inhibiting adhesion of HL-60 cells to Chinese hamster ovary cells transfected with human ICAM-1, at $\mathrm{IC}_{50}$ values of 24.3 and $27.2 \mu \mathrm{g} / \mathrm{mL}$.

\section{Streptochlorin}

The bacterial strain designated as Streptomyces sp. 04DH110 was isolated from marine sediment collected from Ayajin Bay, on the East Sea of Korea. The strain yielded an antiproliferative compound streptochlorin, with 4-chloro-5-(1Hindol-3-yl) oxazole as a gross structure. In the sulforhodamine B (SRB) assay, streptochlorin exhibited significant in vitro growth inhibitory activity against $\mathrm{K} 562$ cell lines with $\mathrm{IC}_{50}$ value of $1.05 \mu \mathrm{g} / \mathrm{ml}$ ) and immortalized hepatocytes (CHANG) derived from normal human liver (with $\mathrm{IC}_{50}$ value of $10.9 \mu \mathrm{g} / \mathrm{ml}$ ) (Shin et al. 2007). Investigating the pro-apoptotic effect of streptochlorin in human leukemic U937 cells, it was found that the pro-apoptotic effect of streptochlorin is mediated through activation of caspases and mitochondria in U937 cells (Park et al. 2008; Shin et al. 2008a). Streptochlorin also exhibited antiangiogenic activity by inhibition of endothelial cell invasion and tube formation stimulated with vascular endothelial cell growth factor, by interrupting the TNF- $\alpha$-induced NF- $\kappa B$ activation (Choi et al. 2007).

\section{Streptopyrrolidine}

Streptomyces sp. KORDI-3973 isolated from a deep-sea sediment sample collected at Ayu Trough, yielded a benzyl pyrrolidine derivative, streptopyrrolidine. The compound exhibited antiangiogenesis activity and blocked the capillary tube formation without showing cytotoxicity against HUVECs at the concentration of $100 \mu \mathrm{g} / \mathrm{ml}$ (Shin et al. 2008b).

\section{Caboxamycin}


A benzoxazole compound named caboxamycin, was reported to be produced from the culture extract of Streptomyces sp. NTK 937, which was isolated from an Atlantic ocean deep-sea sediment core collected near the Canary Islands. Cytotoxicity analysis of caboxamycin showed moderate growth inhibitory activity towards AGS, HepG2 and MCF7 cell lines with $\mathrm{GI}_{50}$ of $7.5,7.4$ and $7.3 \mu \mathrm{g} / \mathrm{mL}$, respectively (Hohmann et al. 2009b).

\section{Ammosamides}

Streptomyces sp. CNR-698, isolated from bottom sediments collected at a depth of 1618 meters in the Bahamas Islands. The fermentation broth of the strain yielded ammosamides $\mathrm{A}$ and $\mathrm{B}$, a pyrroloiminoquinone compound with thio- $\gamma$-lactam functionality. The compounds exhibited significant in vitro cytotoxicity against HCT-116 cell lines, each with $\mathrm{IC}_{50}$ value of $320 \mathrm{nM}$. Further the molecular target of the ammosamides was identified as a member of the myosin family, important cellular proteins that are involved in cell cycle regulation, cytokinesis, and cell migration (Hughes et al. 2009).

\section{Dermacozine}

Dermacozines A-G are phenazine alkaloids, isolated from Dermacoccus abyssi sp. nov., strains MT1.1 and MT1.2, which was derived from Mariana Trench sediment. The compounds exhibited low cytotoxicity against K562 cell line among which highest cytotoxicity was observed for dermacozines $\mathrm{F}$ and $\mathrm{G}$ with $\mathrm{IC}_{50}$ value of 9 and 7 $\mu \mathrm{M}$, respectively (Abdel-Mageed et al. 2010).

\section{N-(2-hydroxyphenyl)-2-phenazinamine:}

Nocardia dassonvillei BM-17 was isolated from a sediment sample collected in the Arctic ocean. The culture broth yielded a novel metabolite $\mathrm{N}$-(2hydroxyphenyl)-2-phenazinamine (NHP) and six known antibiotics. NHP displayed potent cytotoxicity against HepG2, A549, HCT-116 and COC1cell lines among which high cytoxicity was observed against HCT-116 with $\mathrm{IC}_{50}$ value of 27.82 $\mu \mathrm{g} / \mathrm{ml}$ (Gao et al. 2012).

\section{REQUIREMENT OF TARGETED RESEARCH}

Screening the culture extracts of actinobacteria for anticancer activity by in vitro assays has been the existing method for identification of potential actinobacteria. In vivo bioassays also augment the traditional cell based screening method for anticancer drugs. Random screening may lead to discovering anticancer metabolites from actinobacteria, but focused research through gene based screening methods are still more effective in discovering lead compounds. Though successful, contemporary screening protocols need to be coupled with promising new strategies for efficient cancer treatment. Thus widening the scope of finding novel and efficient drugs to treat cancer involves tremendous knowledge about tumour biology. With enormous progress in significant understanding about cancer progression, utilization of technical capabilities towards targeted research is the fundamental criteria for successful screening of antitumorales from actinobacteria. Achieving effective cancer therapy requires integrative approach of experimentation and underlies exploring molecular targets of cancer. Functional screening of the metabolites not only reveals novel mechanism of action but also prove out to be successful targets of cancer therapy by exploitation of the selective and specific biological activities of the metabolites such as inhibitors of protein-protein interactions and cell cycle targets (Aggarwal et al. 2006). Inhibition of proteasome function has emerged as a powerful strategy for anti-cancer therapy (Crawford et al. 2011). Thus evaluating the ability of the bioactive compounds from marine actinobacteria, to inhibit aromatase and proteasome using various noncellular, cell-based and in vivo assays will be an effective screening strategy to develop anticancer metabolite. Optimizing through these specific targets would thus prove out to be efficient method of search for cancer therapeutics.

\section{INSILICO APPROACH}

The successful genome mining is effectively encouraged by focusing on insilico recognition of the most promising targets within genome. The correct identification of potential gene clusters for secondary metabolites is thus effectively accomplished using specialized bioinformatics tools and resources. This facilitates the natural product discovery to a greater extent, for the reliable prediction of the genes involved in the secondary metabolism, and gaining insight about the metabolite, further supports in reduction of the timeline involved in the drug discovery process, thus accelerating experimental research. Few of the insilico methods which are already in use to 
automate the analysis of secondary metabolism in microbes, are listed below in table 7 .

Table 7 - Insilico methods

\begin{tabular}{|c|c|}
\hline Tools/ Programs/ Databases & Reference \\
\hline antiSMASH (antibiotics \& Secondary Metabolite & Medema et al. 2011; Blin et al. 2013 \\
\hline Analysis Shell) & \\
\hline BAGEL3 & de Jong et al. 2010; van Heel et al. 2013 \\
\hline CLUSEAN (Cluster Sequence Analyzer) & Weber et al. 2009 \\
\hline ClustScan & Starcevic et al. 2008 \\
\hline MIDDAS-M & Umemura et al. 2013 \\
\hline NaPDoS (Natural Product Domain Seeker) & Ziemert et al. 2012 \\
\hline NP.searcher (Natural Product searcher) & Li et al. 2009 \\
\hline NRPSPredictor & Röttig et al. 2011 \\
\hline PKMiner & Kim and Yi 2012 \\
\hline $\begin{array}{l}\text { SBSPKS (Structure Based Sequence Analysis of } \\
\text { Polyketide Synthases) }\end{array}$ & Anand et al. 2010 \\
\hline SEARCHPKS & Yadav et al. 2003 \\
\hline $\begin{array}{l}\text { SMURF (Secondary Metabolite Unknown Regions } \\
\text { Finder) }\end{array}$ & Khaldi et al. 2010 \\
\hline
\end{tabular}

\section{CONCLUSION}

Understanding the dynamics of cancer is the essence to develop adequate therapies. Also, supreme importance is needed in perceiving the molecular mechanisms adapted by tumor cells in the development of resistance against multiple drugs. Insilico approach to decipher biosynthetic potential complements the traditional screening methodology and thus augmenting the drug research. With discrete pharmaceutical and biotechnological applications, actinobacteria render them as promising therapeutic agents. The bioactive compounds with distinct chemical structures, from marine actinobacteria are thus promising dominant leads in cancer drug discovery. Harnessing the biological capabilities of marine actinobacteria through systematic and intensive research and exposing new platforms of study could pave way for sustained discovery of potential bioactive compounds for therapeutic use.

\section{REFERENCES}

Abdel-Mageed WM, Milne BF, Wagner M, Schumacher M, Sandor P, Pathom-aree W. Dermacozines, a new phenazine family from deep-sea dermacocci isolated from a Mariana Trench sediment. Org Biomol Chem. 2010; 8 (10): 2352-62.

Aggarwal BB, Sethi G, Nair A, Ichikawa H. Nuclear factor-B: a Holy Grail in cancer prevention and therapy. Curr Signal Transduction Therapy. 2006; 1 (1): 25-52.

Anand S, Prasad MV, Yadav G, Kumar N, Shehara J, Ansari MZ, Mohanty D. SBSPKS: structure based sequence analysis of polyketide synthases. Nucleic Acids Res. 2010; 38: W487-W496.

Asolkar RN, Maskey RP, Helmke E, Laatsch H. Chalcomycin B, a new macrolide antibiotic from the marine isolate Streptomyces sp. B7064. J Antibiot. 2002; 55, 893-898.

Asolkar RN, Jensen PR, Kauffman CA and Fenical W. Daryamides A-C weakly cytotoxic polyketides from a marine derived actinomycete of the genus Streptomyces strain CNQ-085. J Nat Prod. 2006; 69: 1756-1759.

Asolkar RN, Freel KC, Jensen PR, Fenical W, Kondratyuk TP, Park E-J. ArenamidesA-C, cytotoxic $\mathrm{NF}-\kappa \mathrm{B}$ inhibitors from the marine Actinomycete Salinispora arenicola. J Nat Prod. 2009; 72 (3): 396402.

Berdy J. Bioactive microbial metabolites. A personal view. J. Antibiot. 2005; 58: 1-26.

Blin K, Medema MH, Kazempour D, Fischbach M, Breitling R, Takano E, Weber T. antiSMASH $2.0-\mathrm{a}$ versatile platform for genome mining of secondarymetabolite producers. Nucleic Acids Res. 2013; 41: W204-W212.

Borrel MN, Pereira E, Fiallo M, Garnier Suillerot A. Mobile ionophores are a novelclass of P-glycoprotein inhibitors. Eur J Biochem. 2005; 223 (1): 125-33. 
Bugni TS, Woolery M, Kauffman CA, Jensen PR, Fenical W. Bohemamines from a marine-derived Streptomyces sp. J Nat Prod. 2006; 69: 1626-1628.

Burg R W, Miller B M, Baker E E, Birnbaum J, Currie S A, Hartman R. Avermectins, new family of potent anthelmintic agents: producing organism and fermentation. Antimicrob Agents Chemother. 1979; 15 (3): 361-367.

Burgess JG. New and emerging analytical techniques for marine biotechnology. Curr Opin Biotechnol. 2012; 23: 29-33.

Carlson J C, Li S, Burr D A, Sherman D H. Isolation and characterization of tirandamycins from a marinederived Streptomyces sp. J Nat Prod. 2009; 72: 2076-2079.

Che Q, Zhu T, Qi X, Mándi A, Kurtán T, Mo X, Li J, $\mathrm{Gu} \mathrm{Q}, \mathrm{Li}$ D. Hybrid Isoprenoids from a Reeds Rhizosphere Soil Derived Actinomycete Streptomyces sp. CHQ-64. Org Lett. 2012; 14: 34383441.

Che Q, Zhu T, Keyzers RA, Liu X, Li J, Gu Q, Li D. Polycyclic Hybrid Isoprenoids from a Reed Rhizosphere Soil Derived Streptomyces sp. CHQ-64. J Nat Prod. 2013; 76: 759-763.

Cho JY, Kwon HC, Williams PG, Kauffman CA, Jensen PR, Fenical W. ActinofuranonesA and B, polyketides from a marine-derived bacterium related to the genus Streptomyces (Actinomycetales). J Nat Prod. 2006; 69 (3): 425-8.

Cho JY, Williams PG, Kwon HC, Jensen PR, Fenical W. Lucentamycins AD, cytotoxic peptides from the marine-derived actinomycete Nocardiopsis lucentensis. J NatProd. 2007; 70 (8): 1321-8.

Choi IK, Shin HJ, Lee HS, Kwon HJ. Streptochlorin, a marine natural product, inhibits NF- $\kappa$ B activation and suppresses angiogenesis in vitro. J Microbiol Biotechnol. 2007; 17: 1338-1343.

Crawford LJ, Walker B, Irvine AE. Proteasome inhibitors in cancer therapy. J Cell Commun Signal. 2011; 5 (2): 101-110.

Dasari VRRK, Muthyala MKK, Nikku MY, Donthireddy SRR. Novel Pyridinium compound from marine actinomycete, Amycolatopsis alba var. nov., DVR D4 showing antimicrobial and cytotoxic activities in vitro. Microbiol Res. 2012; 167: 346-51.

de Jong A, van Heel AJ, Kok J, Kuipers OP. BAGEL2: mining for bacteriocinsin genomic data. Nucleic Acids Res. 2010; 38: W647-W651.

Feling RH, Buchanan GO, Mincer TJ, Kauffman CA, Jensen PR, Fenical W. Salinospo-ramide A: a highly cytotoxic proteasome inhibitor from a novel microbial source, a marine bacterium of the new genus Salinospora. Angew Chem Int Ed. 2003; 42 (3): 355-7.

Fiedler H-P, Bruntner C, Riedlinger J, Bull AT, Knutsen G, Goodfellow M. Proximicin A, B and C, novel aminofuran antibiotic and anticancer compounds isolated from marine strains of the actinomycete Verrucosispora. J Antibiot. 2008; 61 (3): 158-63.

Fu P, Wang SX, Hong K, Li X, Liu PP, Wang Y. Cytotoxic bipyridines from the marine-derived actinomycete Actinoalloteichus cyanogriseus WH12216-6. J Nat Prod. 2011a; 74: 1751-1756.

Fu P, Liu PP, Li X, Wang Y, Wang SX, Hong K, Zhu WM. Cyclic bipyridine glycosides from the marinederived actinomycete Actinoalloteichus cyanogriseus WH1-2216-6. Org Lett. 2011b; 13: 5948-5951.

Fu P, Yang C, Wang Y, Liu P, Ma Y, Xu L. Streptocarbazoles A and B, two novel indolocarbazoles from the marine derived actionmycete strain Streptomyces sp. FMA. Org Lett. 2012; 14: 2422-2425.

Gao X, Lu Y, Xing Y, Ma Y, Lu J, Bao W. A novel anticancer and antifungus phenazine derivative from a marine actinomycete BM-17. Microbiol Res. 2012; 167: 616-622.

Goodfellow M, Williams ST. Ecology of actinomycetes. Annu. Rev. Microbiol. 1983; 37: 189-216.

Gorajana A, Kurada BV, Peela S, Jangam P, Vinjamuri S, Poluri E, Zeeck A. 1-Hydroxy-1-norresistomycin, a new cytotoxic compound from a marine actinomycete, Streptomyces chibaensis AUBN1/7. J Antibiot. 2005; 58: 526-529.

Gorajana A, Vinjamuri S, Kurada BV, Peela S, Jangam $\mathrm{P}$, Poluri E. Resistoflavine,cytotoxic compound from a marine actinomycete, Streptomyces chibaensis AUBN1/7. Microbiol Res. 2007; 162 (4): 322-7.

Han XX, Cui CB, Gu QQ, Zhu WM, Liu HB, Gu JY, Osada H. ZHD-0501, a novel naturally occurring staurosporine analog from Actinomadura sp. 007. Tetrahedron Lett. 2005; 46: 6137-6140.

Hardt IH, Jensen PR, Fenical W. Neomarinone, and new cytotoxic marinone derivatives, produced by a marine filamentous bacterium (Actinomycetales).Tetrahedron Lett . 2000; 41 (13): 2073-6.

Hawas UW, Shaaban M, Shaaban KA, Speitling M, Maier A, Kelter G. Mansouramycins A-D, cytotoxic isoquinolinequinones from a marine Streptomycete. J Nat Prod. 2009; 72 (12): 2120-4.

Hayakawa Y, Shirasaki S, Kawasaki T, Matsuo Y, Adachi K, Shizuri Y. Structures of new cytotoxic antibiotics, piericidins C7 and C8. J Antibiot. 2007a; 60 (3): 201-3

Hayakawa Y, Shirasaki S, Shiba S, Kawasaki T, Matsuo Y, Adachi K. PiericidinsC7 and C8, new cytotoxic antibiotics produced by a marine Streptomyces sp. $J$ Antibiot. 2007b; 60 (3): 196-200.

Helaly S E, Pesic A, Fiedler H P, Süssmuth R D. Elaiomycins B and C: alkylhydrazide antibiotics from Streptomyces sp. BK 190. Org Lett. 2011; 13 (5): 1052-1055.

Hohmann C, Schneider K, Bruntner C, Brown R, Jones AL, Goodfellow M. Albidopyrone, a new $\alpha$-pyrone- 
containing metabolite from marine-derived Streptomyces sp. NTK 227. J Antibiot. 2009a; 62 (2): 75-9.

Hohmann C, Schneider K., Bruntner C, Irran E, Nicholson G, Bull AT, Jones AL, Brown R, Stach JE, Goodfellow M, Beil W, Krämer M, Imhoff JF, Süssmuth RD, Fiedler HP. Caboxamycin, a new antibiotic of the benzoxazole family produced by the deep-sea strain Streptomyces sp. NTK 937. J Antibiot. 2009b; 62: 99-104.

Hughes CC, MacMillan JB, Gaudêncio SP, Jensen PR, Fenical W. The ammosamides: structures of cell cycle modulators from a marine-derived Streptomyces species. Angew Chem Int Ed Engl. 2009; 48: 725-727.

Jensen PR, Williams PG, Oh DC, Zeigler L and Fenical W. Species-specific secondary metabolite production in marine actinomycetes of the genus Salinispora. Appl Environ Microbiol. 2007; 73: 1146-1152.

Jeong SY, Shin HJ, Kim TS, Lee HS, Park SK, Kim HM. Streptokordin, a new cytotoxic compound of the methylpyridine class from a marine-derived Streptomyces sp. KORDI-3238. J Antibiot. 2006; 59 (4): 234-40.

Kalaitzis JA, Hamano Y, Nilsen G, Moore BS. Biosynthesis and structural revision of neomarinone. Org Lett. 2003; 5 (23): 4449-52.

Kanoh K, Matsuo Y, Adachi K, Imagawa H, Nishizawa M, Shizuri Y. MechercharmycinsA and B, cytotoxic substances from marine-derived Thermoactinomyces sp. YM3-251. J Antibiot. 2005; 58 (4): 289-92.

Khaldi N, Seifuddin FT, Turner G, Haft D, Nierman WC, Wolfe KH, Fedorova ND. SMURF: Genomic mapping of fungal secondary metabolite clusters. Fungal Genet Biol. 2010; 47: 736-741.

Kim WG, Kim JP, Kim CJ, Lee KH, Yoo ID. Benzastatins A, B, C, D: New free radical scavengers from Streptomyces nitrosporeus 30643. I. Taxonomy, fermentation, isolation and physicochemical properties and biological activities. $J$ Antibiot. 1996; 49: 20-25.

Kim J, Yi GS. PKMiner: a database for exploring type II polyketide synthases. BMC Microbiol. 2012; 12: 169.

Kornsakulkarn J, Saepua S, Boonruangprapa T, Suphothina S, Thongpanchang C. New $\beta$-carboline and indole alkaloids from Actinomycete Actinomadura sp. BCC 24717. Phytochem. Lett. 2013; 6: 491-494.

Kwon HC, Kauffman CA, Jensen PR, Fenical W. Marinomycins A-D, antitumor antibiotics of a new structure class from a marine actinomycete of the recently discovered genus "Marinispora". J. Am. Chem. Soc. 2006; 128: 1622-1632.

Lee J G, Yoo I D, Kim W G. Differential antiviral activity of benzastatin $\mathrm{C}$ and its dechlorinated derivative from Streptomyces nitrosporeus. Biol Pharm Bull. 2007; 30 (4): 795-797.
Li F, Maskey RP, Qin S, Sattler I, Fiebig HH, Maier A. Chinikomycins A and B:Isolation, structure elucidation, and biological activity of novel antibiotics froma marine Streptomyces sp. isolate M045. J Nat Prod. 2005; 68 (3): 349-53.

Li DH, Zhu TJ, Liu HB, Fang YC, Gu QQ, Zhu WM. Four butenolides are novel cytotoxic compounds isolated from the marine-derived bacterium, Streptoverticillium luteoverticillatum 11014. Arch Pharm Res. 2006; 29; 624-626.

Li MH, Ung PM, Zajkowski J, Garneau-Tsodikova S, Sherman DH. Auto-mated genome mining for natural products. BMC Bioinformatics. 2009; 10: 185.

Liu R, Zhu T, Li D, Gu J, Xia W, Fang Y, Liu H, Zhu W, Gu Q. Two indolocarbazole alkaloids with apoptosis activity from a marine-derived actinomycete Z2039-2. Arch Pharm Res. 2007; 30: 270-274

Lorico A, Long BH. Biochemical characterisation of elsamicin and other coumarin-related antitumour agents as potent inhibitors of human topoisomerase II. Eur. J. Cancer. 1993; 29A: 1985-1991.

Lu J, Ma Y, Liang J, Xing Y, Xi T, Lu Y. Aureolic acids from a marine-derived Streptomyces sp. WBF16. Microbiol Res. 2012; 167: 590-5.

Macherla VR, Liu J, Bellows C, Teisan S, Nicholson B, Lam KS. Glaciapyrroles A, B, and C, pyrrolosesquiterpenes from a Streptomyces $\mathrm{sp}$. isolated from an Alaskan marine sediment. $J$ Nat Prod. 2005; 68 (5): 780-3.

Manam RR, Teisan S, White DJ, Nicholson B, Grodberg J, Neuteboom ST, Lam KS, Mosca DA, Lloyd GK, Potts BC. Lajollamycin, a nitro-tetraene spiro-betalactone-gamma-lactam antibiotic from the marine actinomycete Streptomyces nodosus. J Nat Prod. 2005; 68: 240-243.

Martin GD, Tan LT, Jensen PR, Dimayuga RE, Fairchild CR, Raventos-Suarez C, Fenical W. Marmycins A and $\mathrm{B}$, cytotoxic pentacyclic $\mathrm{C}$-glycosides from a marine sediment derived actinomycete related to the genus Streptomyces. J Nat Prod. 2007; 70: 14061409.

Maskey RP, Li FC, Qin S, Fiebig HH, Laatsch H. Chandrananimycins AC: Production of novel anticancer antibiotics from a marine Actinomadura sp. isolate M048 by variation of medium composition and growth conditions. J Antibiot. 2003; 56: 622629.

Maskey R P, Helmke E, Kayser O, Fiebig H H, Maier A, Busche A.Anti-cancer and antibacterial trioxacarcins with high anti-malaria activity from a marine Streptomycete and their absolute stereochemistry. J Antibiot. 2004; 57 (12): 771-779.

McGovren JP, Neil GL, Crampton SL, Robinson MI, Douros JD. Antitumor activity and preliminary drug disposition studies on chartreusin (NSC 5159). Cancer Res. 1977; 37: 1666-1672. 
Medema $\mathrm{MH}$, Blin $\mathrm{K}$, Cimermancic $\mathrm{P}$, de Jager V, Zakrzewski P, Fischbach MA, Weber T, Takano E, Breitling R. antiSMASH: rapid identification,annotation and analysis of secondary metabolite biosynthesis gene clusters inbacterial and fungal genome sequences. Nucleic Acids Res. 2011; 39: W339-W346.

Miller ED, Kauffman CA, Jensen PR, Fenical W. Piperazimycins: cytotoxic hexadepsipeptides from a marine-derived bacterium of the genus Streptomyces. J Org Chem. 2007; 72 (2): 323-30.

Mitchell SS, Nicholson B, Teisan S, Lam KS, Barbara C. Aureoverticillactam, a novel22-atom macrocyclic lactam from the marine actinomycete Streptomyces aureoverticillatus. J Nat Prod. 2004; 67 (8): 1400-2.

Moore B S, Trischman J A, Seng D, Kho D, Jensen P R, Fenical W. Salinamides, antiinflammatory depsipeptides from a marine streptomycete. $\mathrm{J} \mathrm{Org}$ Chem. 1999; 64 (4): 1145-1150.

Okazaki T, Kitahara T, Okami Y. Studies on marine microorganisms. IV. A new antibiotic SS-228 Y produced by Chainia isolated from shallow sea mud. J. Antibiot. 1975; 28: 176-184.

Park C, Shin HJ, Kim GY, Kwon TK, Nam TJ, Kim SK, Cheong J, Choi IW, Choi YH. Induction of apoptosis by streptochlorin isolated from Streptomyces sp. in human leukemic U937 cells. Toxicol In vitro. 2008; 22: 1573-1581.

Pathirana C, Jensen PR, Fenical W. Marinone and debromomarinone: antibiotic sesquiterpenoid naphthoquinones of a new structure class from a marine bacterium. Tetrahedron Lett. 1992; 33 (50): 7663-6.

Pérez M, Crespo C, Schleissner C, Rodríguez P, Zúñiga $\mathrm{P}$, Reyes F. Tartrolon D, a cytotoxic macrodiolide from the marine-derived actinomycete Streptomyces sp. MDG-04-17-069. J Nat Prod. 2009; 72: 2192 2194.

Renner MK, Shen Y-C, Cheng X-C, Jensen PR, Frankmoelle W, Kauffman CA. New antiinflammatory cyclic peptides produced by a marine bacterium (Streptomyces sp.). J Am Chem Soc. 1999; 121 (49): 11273-6.

Riedlinger J, Reicke A, Zähner H, Krismer B, Bull AT, Maldonado LA. Abyssomicins, inhibitors of the para-aminobenzoic acid pathway produced bythe marine Verrucosispora strain AB-18-032. J Antibiot. 2004; 57 (4): 271-9.

Röttig M, Medema MH, Blin K, Weber T, Rausch C, Kohlbacher O. NRP-Spredictor2 - a web server for predicting NRPS adenylation domain specificity. Nucleic Acids Res. 2011; 39: W362-W367.

Sato S, Iwata F, Yamada S, Kawahara H, Katayama M. Usabamycins A-C: new anthramycin-type analogues from a marine-derived actinomycete. Bioorg MedChem Lett. 2011; 21 (23): 7099-101.

Schneider K, Keller S, Wolter FE, Röglin L, Beil W, Seitz O, Nicholson, G, Bruntner C, Riedlinger J,
Fiedler HP, Süssmuth RD. Proximicins A, B, and Cantitumor furan analogues of netropsin from the marine actinomycete Verrucosispora induce upregulation of p53 and the cyclin kinase inhibitor p21. Angew Chem Int Ed Engl. 2008; 47: 3258-3261. Schultz AW, Oh D-C, Carney JR, Williamson RT, Udwary DW, Jensen PR. Biosynthesis and structures of cyclomarins and cyclomarazines, prenylated cyclic peptides of marine actinobacterial origin. $\mathrm{J} \mathrm{Am}$ Chem Soc. 2008; 130 (13): 4507-16.

Shin HJ, Jeong HS, Lee HS, Park SK, Kim HM, Kwon HJ. Isolation and structure determination of streptochlorin, an antiproliferative agent from a marine-derived Streptomyces sp. 04DH110. J Microbiol Biotechnol. 2007; 17: 1403-1406.

Shin DY, Shin HJ, Kim GY, Cheong J, Choi IW, Kim SK, Moon SK, Kang HS, Choi YH. Streptochlorin isolated from Streptomyces sp. Induces apoptosis in human hepatocarcinoma cells through a reactive oxygen species-mediated mitochondrial pathway. $J$ Microbiol Biotechnol. 2008a; 18: 1862-1868.

Shin HJ, Kim TS, Lee H-S, Park JY, Choi I-K, Kwon HJ. Streptopyrrolidine, anangiogenesis inhibitor from a marine-derived Streptomyces sp. KORDI-3973. Phytochemistry. 2008b; 69 (12):2363-6.

Soria-Mercado IE, Prieto-Davo A, Jensen PR, Fenical W.Antibiotic terpenoid chlorodihydroquinones from a new marine actinomycete. J Nat Prod. 2005; 68 (6): 904-910.

Starcevic A, Zucko J, Simunkovic J, Long PF, Cullum J, Hranueli D. ClustScan: an integrated program package for the semi-automatic annotation of modular biosynthetic gene clusters and in silico prediction of novel chemical structures. Nucleic Acids Res. 2008; 36: 6882-6892.

Stritzke K, Schulz, Laatsch H, Helmke E, Beil W. Novel caprolactones from a marine streptomycete. $\mathrm{J} \mathrm{Nat}$ Prod. 2004; 67: 395-401.

Takahashi A, Ikeda D, Nakamura H, Naganawa H, Kurasawa S, Okami Y, Takeuchi T, Iitaka Y. Altemicidin, a new acaricidal and antitumor substance. II. Structure determination. J Antibiot. 1989a; 42: 1562-1566.

Takahashi A, Kurasawa S, Ikeda D, Okami Y, Takeuchi T. Altemicidin, a new acaricidal and antitumor substance. I. Taxonomy, fermentation, isolation and physico-chemical and biological properties. $J$ Antibiot. 1989b; 42: 1556-1561.

Umemura M, Koike H, Nagano N, Ishii T, Kawano J, Yamane N, Kozone I, Hori-moto K, Shin-Ya K., Asai $\mathrm{K}$, Yu J, Bennett JW, Machida M. MIDDASM:motif-independent de novo detection of secondary metabolite gene clustersthrough the integration of genome sequencing and transcriptome data. PLoSONE. 2013; 8: e84028.

van Heel AJ, de Jong A, Montalban-Lopez M, Kok J, Kuipers OP. BAGEL3:automated identification of genes encoding bacteriocins and (non-)bactericidal 
post translationally modified peptides. Nucleic Acids Res. 2013; 41, W448-W453.

Waksman SA. The Actinomycetes: Isolation, identification, cultivation and preservation. Baltimore, Williams \& Wilkins Company. 1959; 17 28.

Watve MG, Tickoo R, Jog MM, and Bhole BD. How many antibiotics are produced by the genus Streptomyces? Arch Microbiol. 2001; 176: 386-390.

Weber T, Rausch C, Lopez P, Hoof I, Gaykova V, Huson DH, Wohlleben W. CLUSEAN: a computer-based framework for the automated analysis of bacterial secondary metabolite biosynthetic gene clusters. $J$ Biotechnol. 2009; 140: 13-17.

William PG, Asolkar RN, Kondratyuk T, Pezzuto JM, Jensen PR and Fenical W. Saliniketals A and B, bicyclic polyketides from the marine actinomycete Salinispora arenicola. J Nat Prod. 2007a; 70: 83-88.

Williams PG, Miller ED, Asolkar RN, Jensen PR, Fenical W. Arenicolides A-C, 26- membered ring macrolides from the marine actinomycete Salinispora arenicola. J Org Chem. 2007b; 72: 5025-5034.
Wu SJ, Fotso S, Li F, Qin S, Kelter T, Fiebig HH. 39-Ncarboxamidostaurosporineand selina-4(14),7(11)diene-8,9-diol, new metabolites from a marine Streptomyces sp. J Antibiot. 2006; 59: 331-7.

Wu SJ, Fotso S, Li F, Qin S, Laatsch H. Amorphane sesquiterpenes from a marine Streptomyces sp. J Nat Prod. 2007; 70 (2): 304-6.

Yadav G, Gokhale RS, Mohanty D. SEARCHPKS: a program for detection and analysis of polyketide synthase domains. Nucleic Acids Res. 2003; 31: 3654-3658.

Zhang Q, Schrader KK, ElSohly HN, Takamatsu S. New cell-cell adhesion inhibitors from Streptomyces sp. UMA-044. J Antibiot. 2003; 56: 673-681.

Zhang W, Liu Z, Li S, Yang T, Zhang Q, Ma L, Tian X, Zhang H, Huang C, Zhang S. Spiroindimicins A-D: New Bisindole Alkaloids from a Deep-Sea-Derived Actinomycete. Org Lett. 2012; 14: 3364-3367.

Zhang W, Ma L, Li S, Liu Z, Chen Y, Zhang H, Zhang G, Zhang Q, Tian X, Yuan C. Indimicins A-E, Bisindole Alkaloids from the Deep-Sea-Derived Streptomyces sp. SCSIO03032. J Nat Prod. 2014; 77: 1887-1892.

Ziemert N, Podell S, Penn K, Badger JH, Allen E, Jensen PR. The natural product domain seeker NaPDoS: a phylogeny based bioinformatic tool to classify secondary metabolite gene diversity. PLoS ONE. 2012; 7: e34064. 